\title{
32. COMMENTS ON LEG 25 SITES IN RELATION TO THE CRETACEOUS AND PALEOGENE STRATIGRAPHY IN THE EASTERN AND SOUTHEASTERN AFRICA COAST AND MADAGASCAR REGIONAL SETTING
}

\author{
Jacques Sigal, Institut Français du Pétrole, Rueil-Malmaison, France
}

\section{INTRODUCTION}

The holes drilled during Leg 25 show a large degree of diversity. Each had its own objectives and revealed its own stratigraphic findings. They provided some understanding of the nature and age of the deposits and, possibly of the substratum. It is the purpose of this paper to place them in a regional setting and to compare them by enlarging the comparative framework. This wide geologic framework can provide useful data for the interpretation of seismic profiles.

Holes will be compared in three ways, depending on the available data: (1) with data from onshore field observations (sedimentary fringe of African and Madagascar coastal "basins," and coastal boreholes) or from offshore observations (offshore boreholes); (2) with considerations linked to hypotheses about plate tectonics; and (3) with major geological or diastrophic events.

This comparison covers a large area over which a great variety of sedimentary facies is represented. In most areas, published data are sparse. Also, the data which are available do not all have the same comparative value because they not only were obtained progressively as years went by, but also by different techniques. Within the limited space available, I have tried to avoid the two major pitfalls that can waylay any such undertaking, i.e., altering the data through diagrammatic formulating, and writing a report on regional geology. An attempt to avoid these dangers was made by limiting the comparisons to a certain number of crucial problems that concern the drilled sites.

I have tried to overcome the handicap of not having direct personal knowledge about the regions involved by exchanging opinions and publications with various colleagues who have been kind enough to assist me and to whom I willingly extend my thanks. These include $\mathrm{H}$. Besairie (Tananarive), G. Flores (Florence), G. Blant (Entreprise de Recherches et d'Activités Pétrolières, Paris), Compagnie Francaise des Pétroles (P. Burollet, Ph. Dufaure, Cl.de Lapparent, $\mathrm{Ph}$. Trouvé), M Collignon (Gières, France), and A. Balduzzi (A.G.I.P., Milano).

\section{BIOSTRATIGRAPHIC RESULTS}

Discussions of the major stratigraphic problems which have been selected for this chapter are based on three kinds of data: (1) the biostratigraphic columns of the different sites; (2) the photographic plates showing the most important species of foraminifera; and (3) a table of the sequences which have been dated and the hiatuses which are either demonstrated or suspected. The following discussion is based on these data.
The biostratigraphic columns have been given for each site (Chapters 2-10). The distribution (and the recovery. rates) of the cores, the paleontologic zones which have been recognized (planktonic and benthonic foraminifera and calcareous nannofossils), and the geochronologic scale are given in these columns.

It was not possible, because of the time allowed, to write a paleontologic-taxonomic paper on the foraminifera and ostracod assemblages to be included in the Initial Report. However, many results are new because some drilled sequences were originally deposited in a particular realm (very austral for Site 245 for instance) and their monographic study would require much more time.

Plates 1 through 11 illustrate the more important chronostratigraphic species which support the recognized conventional zones or chronostratigraphic determinations. Their purpose is essentially to justify the biochronostratigraphic data on which the delimitations of the drilled sequences and intercalated hiatuses are based. Also, they support the paleogeographic frame in which the sites and the surrounding sedimentary areas can be compared.

The identified parts and the hiatuses of the stratigraphic columns are given in Figure 1, based on their actual range in the scale of "absolute" ages. The figure attempts to show, for each site, those parts of the stratigraphic column which were not recognized. They may thus correspond either to gaps, i.e., nondeposition or erosion, or they may correspond to condensed sequences, as it has been emphasized by Leclaire in the aforementioned chapter. Very probably both explanations must be considered, depending on the site, as it is evident that these "hiatuses" actually occur in very different paleogeographic environments.

The hiatuses are included in a scale of measured ages in order to give the most accurate presentation of data possible. Moreover, the "absolute" age of the lower and upper limits of the hiatuses, as they can be deduced from the biochronologic data, is given. These determinations are the basic elements which enable sedimentation rates to be calculated.

\section{LEG 25 SITES IN A REGIONAL SETTING}

\section{Introduction}

During stratigraphic and paleontologic studies of the Leg 25 sites, several problems became apparent. This part of the paper isolates some of the more important ones and discusses each in a regional setting. These settings have been reconstructed for the various periods under discussion. 


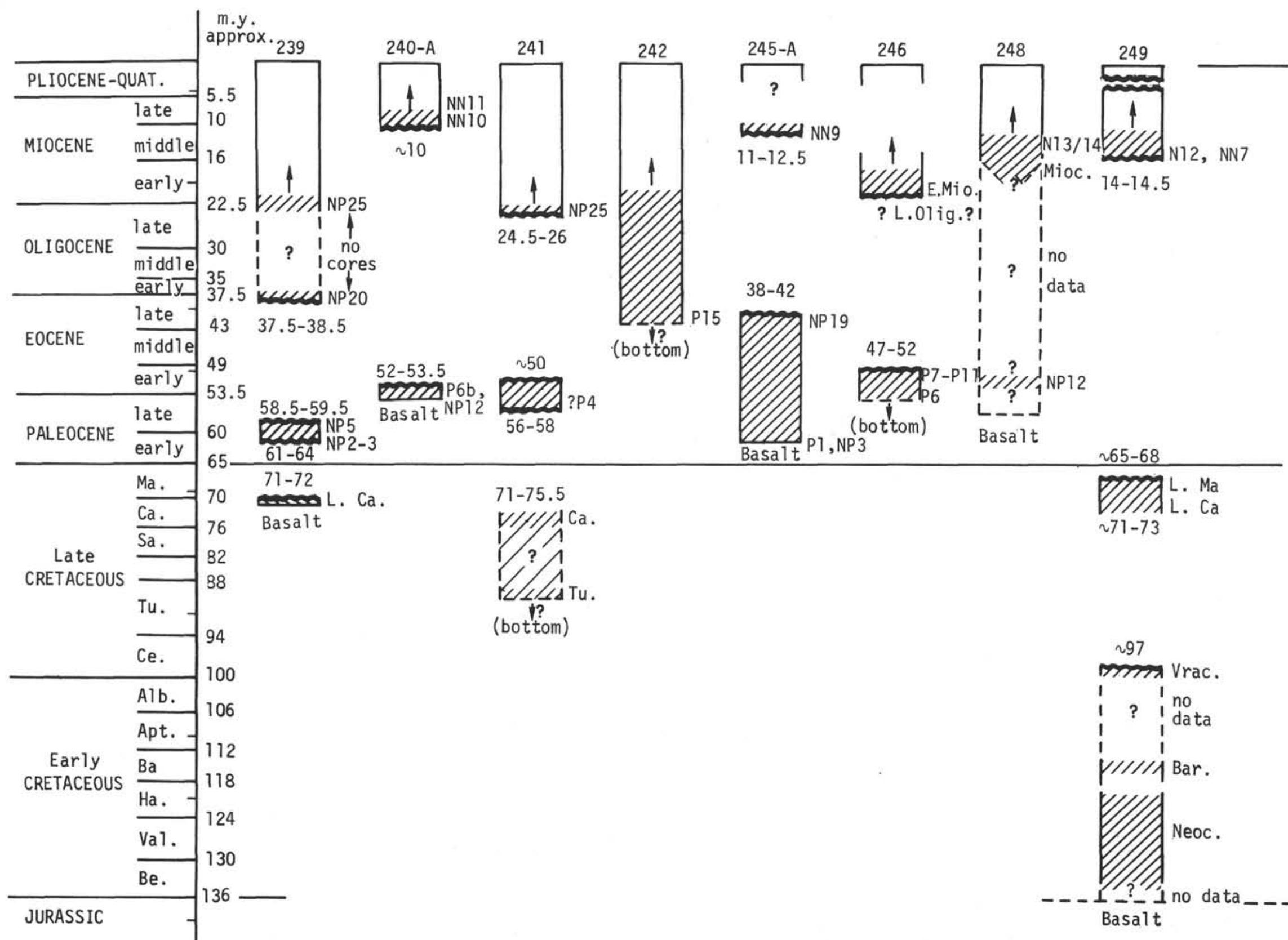

Figure 1. Identified parts and inferred hiatuses of the stratigraphic column from Early Cretaceous to Recent (scale in million years). 
Figure 2 portrays the region $120 \mathrm{~m} . y$. ago, during the Early Cretaceous. Figure 4 is a 75 m.y. reconstruction of the Late Cretaceous and Figures 5 and 6 are reconstructions of the middle Tertiary, 45 and 36 m.y. ago, respectively. Figure 3 is of Madagascar as it appears today with notations of cited localities.

\section{Comments on the Marine Late Jurassic}

The Jurassic was not reached in any of the boreholes. It is fairly certain that it does not exist at Site 249 (at least in the sediment column) despite the fact that the great thickness attributed to the Neocomian might suggest its presence.

In the vicinity of Site 249, the Jurassic of Mozambique and South Africa should be taken into consideration. In Mozambique however, the late Jurassic that has been recognized is located far north of Site 249. Moreover, doubt is cast on this age by G. Flores (1972) because he does not believe that the lamellibranch macrofauna are conclusive proof for that age. A deeper hole at Site 242, perhaps, would have penetrated such old sediments. In southern Tanzania, the late Kimmeridgian and Tithonian also exist. Many authors attribute the role during Cretaceous time of a barrier to the Mozambique axis that is assumed to have limited the south-southwest extension of the Lias and middle and late Jurassic deposits which are quite extensive in Tanzania and Madagascar.

In South Africa, the marine Jurassic (probably Callovian) was recently identified for the first time (Dingle and Klinger, 1971) west of Knysna. It was in the form of sandy and conglomeratic fluviatile deposits associated with a few shallow-marine sandy deposits. Judging from these sediments, this appears to represent a marine incursion of the paralic type, perhaps leading to sediment fill in the troughs which were the first signs of the great fractures that would later break up the Gondwana continent.

\section{Basement of the Neocomian: the Eruptive Rock at Site 249}

Based on what is known onshore in the southern basin in Mozambique, three possibilities for the eruptive rock at Site 249 can be considered. A comparison might be made with Movene basalts which overlie the Lebombo series and underlie the Domo Formation west of Lourenço Marques. These basalts have been dated at $137 \pm 10$ m.y. by the K/Ar method. Similar ones have been found in coastal boreholes underneath marine transgressive Aptian-Albian (Maputo and/or Domo Formation) and unconformable on Goba rhyolites, limburgites, and sandstones, and also on the upper part of Stormberg series (Late Karroo). Another possibility is that an equivalent can be looked for in older eruptive effusions belonging to the Karroo itself. These would then have been followed by a long period of nondeposition. Lastly, we cannot exclude a Neocomian age for these basalts; if this were the case, they will be linked with volcanic evidence whose trace will be found in the overlying sediments. The solution will obviously lie in the absolute dating of the eruptive rock itself.

With regard to Site 249 , mention can be made of the Héloîse hole drilled by Compagnie Francaise des Pétroles, which will be discussed at a later time with regard to the
Early Cretaceous. This hole encountered Late and then Middle Jurassic having the particular feature, as opposed to series of the same age outcropping in Madagascar, of containing small doleritic sills or effusive flows.

\section{Neocomian-Early Cretaceous at Site 249}

The occasional affinities and communities of microfauna mentioned in relation to this site lead one first to turn toward Madagascar for our comparison.

Generally speaking, within the regional setting with which we are concerned here (Figure 2), the Cretaceous marks a new invasion of the sea on the African craton. This was in the form of a transgression which was quite extensive although less widespread than the one in the late Lias-Middle Jurassic time interval.

\section{Comparison with the West Coast of Madagascar}

It can be assumed that during the Early Cretaceous the respective depositional realms for Madagascar and Site 249 were geographically quite close, as suggested by the paleogeographic reconstruction maps published by various authors and as we mentioned in a publication several years ago (Sigal et al., 1970). It is customary to distinguish the two basins of Majunga (with its northern extension toward Diego) and Morondava (with its southern extension toward Cap Sainte Marie) (Figure 3).

In the Majunga Basin, the Early Cretaceous sequence is quite different from that at Site 249 , first, because of the absence of the intervention of continental facies south of the Betsiboka River, and second, because of the absence of volcanic rocks. However, several species, especially among the ostracods, show an affinity. Hence, a biological similarity is shown even though the deposits and geological history are different. Also, from the biological standpoint, it should be added that the foraminiferal microfauna at Site 249, like those in the Algoa Basin, apparently correspond to warmer areas.

In the Morondava Basin, a similar comparison cannot be made from the biological standpoint because of insufficient data. From the historical standpoint, we are also faced with important contradictions even considering that many factors are still unknown because of the poor outcrops. It can be suggested that the Valanginian is the only series that is more or less constant in the basin (except-unfortunately for the comparison we are attempting-farther south, to the south of the Onilahy River where the Valanginian is missing and where the Hauterivian is transgressive on the Callovian). During the Neocomian, it is possible that gaps or perhaps even continental deposits (e.g., in the vicinity of the Mangoky River) can be compared with the relatively limited sequence that is attributed to the Hauterivian(?) and the Barremian at Site 249. In any case, this site differs because of the volcanogenic nature of its sediments.

The Aptian has not yet been described at Site 249. It is true that a great many events may have occurred during the volcano-sedimentary episode shown in Cores 24 and 25 where Radiolaria may provide specific evidence as to the age. In the Morondava Basin, it can also be stated that the Barremian and Aptian, except for some isolated deposits, are poorly known. Do these deposits still belong to the 


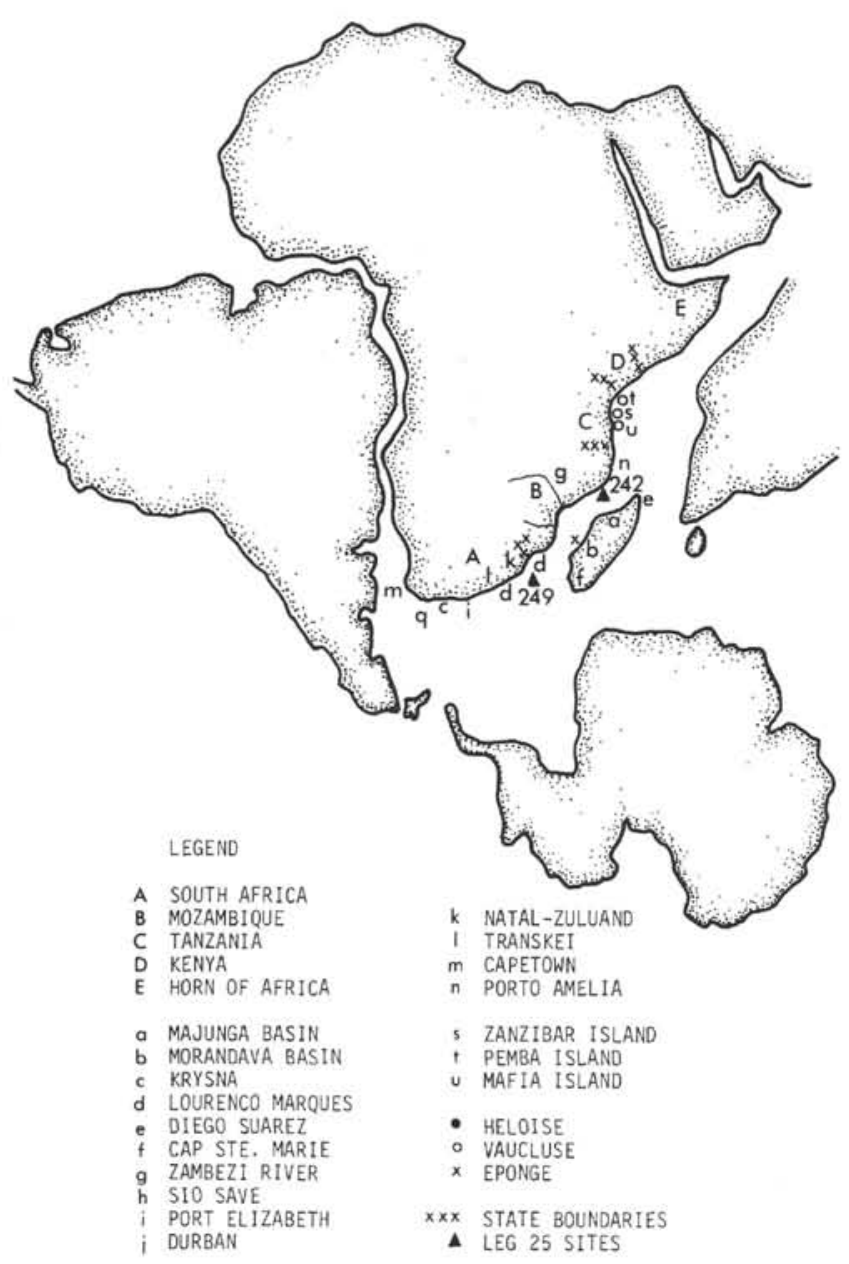

Figure 2. Approximately 120 m.y. ago reconstruction (Neocomian) (according to R. Maack, 1969).

Neocomian Duvalia marls, or already to the AlbianCenomanian continental series? Does the Aptian still exist in its entirety (between the Mangoky and Onilahy rivers, a Clansayesian-summital Aptian transgression is known on the Valanginian or Hauterivian, and in the south the Gargasian is the first stage known)?

Therefore, if we disregard the volcanic influence characterizing Site 249 , we must be content with noting a certain instability, revealed by gaps, which might form a link between the two realms being compared.

Mention should now be made of a nighly important element of comparison provided by the offshore holes Héloïse and Vaucluse (see Figure 3) which were drilled by Compagnie Française des Pétroles (C.F.P.). As opposed to what is found in the outcrops, the "ante-Albian" Early Cretaceous deposits contain interbedded basaltic sills (dolerite and gabbro) in the midst of silty clays and fine sandstones where a few agglutinated foraminifera and Radiolaria are the only microfossils. The C.F.P. geologists considered that these sills might also be the same age as other volcanic evidence found higher up in the holes in the Late Cretaceous. The volcanic phenomena in the Early Cretaceous sediments at Site 249 thus provide new data for choosing between these two interpretations.

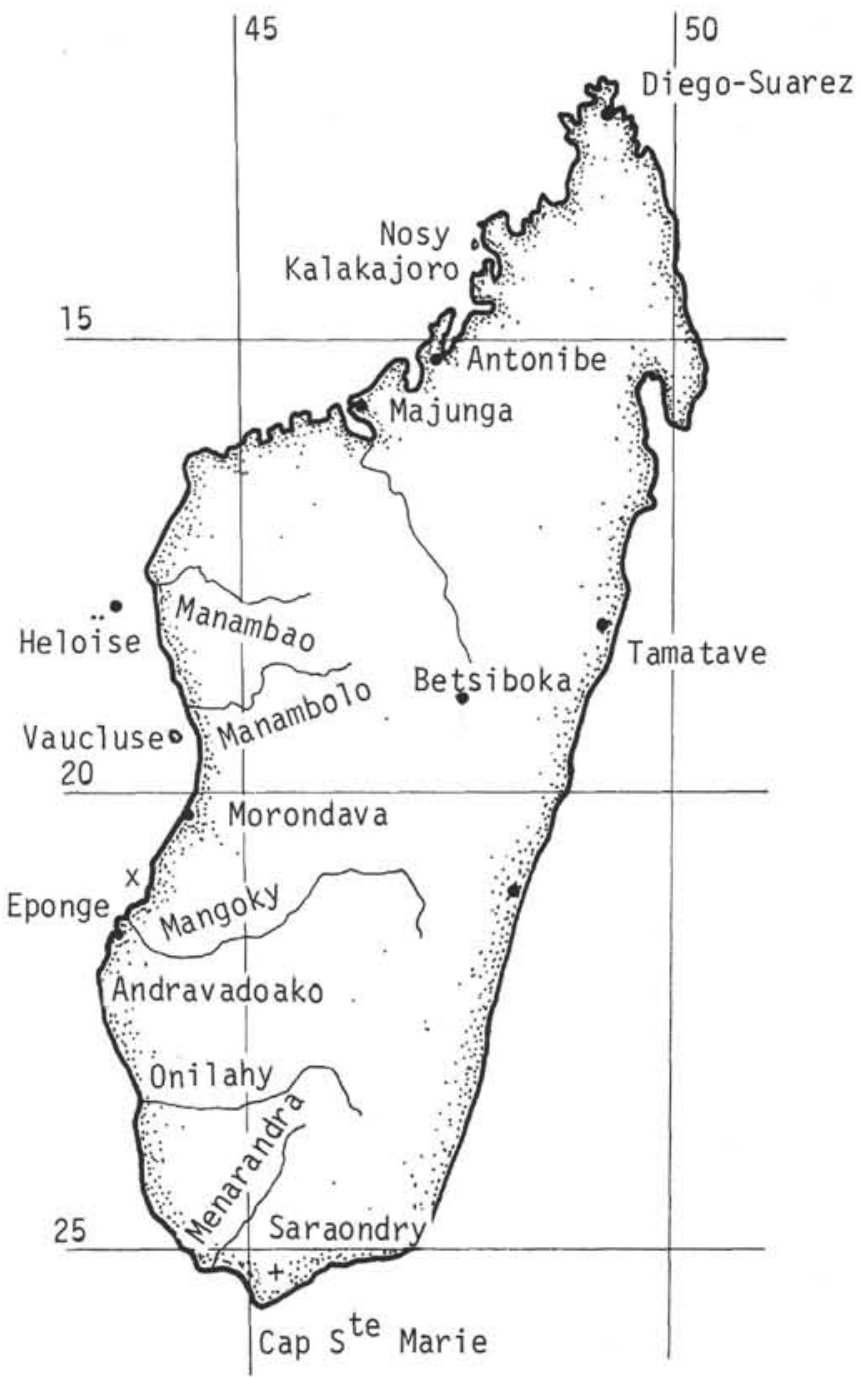

Figure 3. Locality map of Madagascar Island (Scale $1 / 10,000,000)$

\section{Comparison with the Mozambique Coastal Area}

Levels below the Aptian-Albian (i.e., lower than the sandstone-glauconite marine Maputo facies in the southern Mozambique Basin, or the openly marine Porto-Amelia facies in the northern basin) appear to be known only in the northern basin. These beds include: (1) littoral Megatrigonia schwartzi beds considered to be Neocomian and to be the eastern equivalents of the continental facies of the Makonde beds and (2) marine Neocomian with ammonites (Fernao Veloso fauna).

Elsewhere, Neocomian is mostly continental, e.g., in deposits of the Lupata graben where there are interbedded lavas of probable Barremian age (115 \pm 10 m.y.). In some places, igneous rocks have been considered as Neocomian. Some have actually been dated as $115 \pm 10$ m.y., but others are now recognized to be older (e.g., $137 \pm 10$ m.y. for the Movene Basalt). In the coastal holes, the Sena fluviatile facies and the neritic Maputo facies may begin as early as the Neocomian.

Indeed, Flores (1972) points out that to his knowledge drilling between the Save and Zambesi rivers, has not gone 
beyond the "Early Cretaceous-Upper Karoo igneous substratum", which he feels to be made up of isolated effusive rocks that become younger from west to east as the Mozambique Channel formed.

The marine Neocomian at Site 249 is probably more definitely marine than the neritic deposit in the northern basin. The volcanic influx may be a reflection of the same volcanic phenomena which are sometimes included in the Neocomian continental deposits in the southern basin.

\section{Comparison with the South African Coastal Area}

The southern Mozambique Basin (where the Aptian is transgressive) separates the northern part of Mozambique from some small coastal basins in South Africa, beginning south of Durban, where the marine Neocomian is again present.

The marine Neocomian in the Uitenhage series has long been known in a succession of small fault basins of which the largest is the Algoa-Port Elizabeth Basin (Sunday's River beds attributed to the late Valanginian). The Neocomian is also found in Natal and near Cape Agulhas in an offshore area close to Cape Seal. An ostracod species found in the Neocomian at Site 249 can be used to correlate these beds (also dated by foraminifers) with the Sunday's River marine deposits as well as with the Valanginian in the Majunga Basin. The macrofauna in these beds (formerly said to contain Rogersites, but now Holcostephanus) enabled L. F. Spath and M. Collignon long ago to make such correlations. As stated previously, the microfauna in Madagascar probably correspond to a warmer water environment.

In contrast to Site 249 , no volcanic evidence appears to have been found on shore, nor has any been mentioned in the sandstone and conglomerate of the Nbadana beds south of Durban, which tend to be considered as Neocomian rather than Aptian.

The importance of knowing the ages of the deposits at Site 249 at the time of the invasion of the sea during the breakup of Gondwanaland makes it necessary to conduct a detailed investigation using all paleontological techniques now available.

\section{"Middle" Cretaceous at Site 249}

Site 249 yields only two isolated dated levels, one in the Barremian (whose relations with the Neocomian are not clear), and the other in the Albian (cut off by the Campanian at the level of the Vraconian); they enclose an undated volcano-sedimentary sequence (at least in the momentary absence of possible chronological data provided by Radiolaria). Hence, a comparison with onshore data is not easy, which is unfortunate because this is the time when, even in the least mobilist hypothesis for Madagascar, it is admitted that northward drift began (at about the Aptian, after breaking away from India).

\section{Comparison with the West Coast of Madagascar}

The Majunga Basin provides few points of comparison. After a continental interlude (at least southwest of the Betsiboka River) or a gap(?) corresponding to the Barremian-early Aptian time interval, marine or continental late Aptian and Albian are well known for their great facies changes throughout the entire basin. In places, the Gargasian is transgressive over the Neocomian. The transgression becomes more widespread in the Albian. Volcanic influences do not appear to have existed.

In the Morondava Basin, the transgression brought in marine late Aptian or even Albian strata, at least in the southern half of the basin and especially south of the Mangoky River. However, in the central and northern parts, the lower continental sandstone episode in places appears as early as the Albian, and marine interbedding is less extensive. As stated previously, marine Barremian and Aptian have been found locally between Manambao and Manambolo.

Recall that the two boreholes drilled by Compagnie Francaise des Pétroles (Vaucluse and Héloïse) show volcanic evidence interbedded in the midst of deposits attributed to the Middle Cretaceous. Similarly, according to A. Balduzzi (personal communication), the well, Chesterfield 1, yielded a basaltic intercalation which has been dated at $102 \pm 10$ m.y.

\section{Comparison with the Mozambique Coastal Area}

At the level of the Albian-Vraconian fossil-bearing beds at Site 249 , there are deposits with a comparable age in the southern part of the Mozambique sedimentary basin. However, the series (Domo Formation) appears to be more complete there, or at least it is better dated. The Domo facies was deposited in a restricted environment with a strong euxinic influence but contains openly marine planktonic beds. It is considered as an eastern lateral equivalent of the fluviatile sandstone Sena facies and as the gradual succession to either the littoral or neritic Maputo clayey-silty facies or this same Sena facies. These strata apparently range from the Aptian and Albian all the way to the Turonian. The microfossil-bearing levels in Core 23 appear, on the basis of their Gavelinella, to be more recent than the more littoral Aptian facies, which has recently been described (Wachendorf et al., 1967).

An important fact from the paleogeographic standpoint is that the sandy influxes in the Domo Formation probably came from the east, hence from the loation of the positive axis of Mozambique (according to S.N.P.A. Mozambique, in Blant, 1973). Some “Aptian-Albian or slightly older” levels are also found offshore east of Lebombo.

These strata are known to overlie igneous rocks, probably Stormberg, and hence probably have no relation to what occurs at Site 249. In the northern basin, older marine sediment (Megatrigonia beds) is known, but only very locally.

\section{Comparison with the South African Coastal Area}

The Albian is known in Natal (and also some late Aptian south of Mozambique), but the volcano-sedimentary facies at Site 249 is different from the limestones and sandy marls with Cephalopods of these "Umsinene beds". Farther west, mention has also been made of an offshore "Aptian-Albian" south of the Knysna-Plettenberg Bay area, as well as Barremian and Aptian on the eastern side of Agulhas Bank.

In Natal, as in Mozambique, sedimentation continued toward the Late Cretaceous, thus adding to the differences with Site 249. 
To conclude, Site 249 gives evidence of more volcanic activity extending between the Barremian and the Albian. The C.F.P. holes could provide further data on this phenomenon. While on land, either no volcanic evidence has been found prior to the Late Cenomanian locally, and the Turonian in general (Madagascar), or else such evidence comes to an end in the early Cretaceous (African coast).

\section{Late Cretaceous at Site 249}

During the Late Cretaceous (see 75 m.y. reconstruction Figure 4) a comparison also is made difficult at Site 249 by the thin series bounded by two very large hiatuses, one between the Vraconian and the middle Campanian, and the other between the Maestrichtian (not terminal) and the Miocene. However it may be of specific importance to define the context in which these hiatuses occur.

\section{Comparison with the West Coast of Madagascar}

The geological history of the Majunga Basin (Figure 3) appears to be quite different. Its general history includes a largely continental Cenomanian, a Turonian corresponding to an episode of basaltic flows (posterior to the marine early or middle Cenomanian, and anterior to or contemporaneous with the marine late Turonian), and a thick Senonian with an almost solely continental sequence, up to an epicontinental marine Maestrichtian which generalizes the transgression. When comparing Majunga and Site 249, the Maestrichtian, although marine and pelagic in both cases, can be differentiated by the specific composition of the assemblages, probably because of the latitude and different paleoclimatic conditions.

For the time being, we can merely draw a parallel between the very long hiatus separating the late Albian from the Campanian at Site 249 and the extensive movements and the erosion which are indicated at Majunga by the episode of late Cenomanian continental "upper sandstone" and basalt, both locally unconformable (either cartographic or angular) on older formations.

The difference is just as great in the Morondava Basin because only the Campanian-Maestrichtian is represented at Site 249 as opposed to a complete Morondava Late Cretaceous sequence. We schematically know here that two basaltic sequences make up a sort of ribwork. These are the early Campanian "middle" Onilahy basalts in the south, and the "early" Menabe basalts between the Turonian and early Coniacian in the north, and even some as early as the Cenomanian east of Maintirano. Both flows co-exist between the Mangoky and Onilahy rivers in the middle Sikili and the upper Manombo. These basalts are in the midst of a vast continental sequence with numerous marine intercalations (enabling them to be dated), at least in the center of the basin and all the way to the Onilahy River, while nothing remains but a continental Santonian in the south and only a continental Cenomanian-Turonian in the north in the midst of an entirely marine series.

This vast Cenomanian-to-Campanian episode, during which the marine and continental realms interfinger and basalts twice were extruded, is represented at Site 249 only by the very long hiatus already mentioned. Here again, we can only correlate these two histories for the time being. At the most, the locally transgressive nature (in the north of

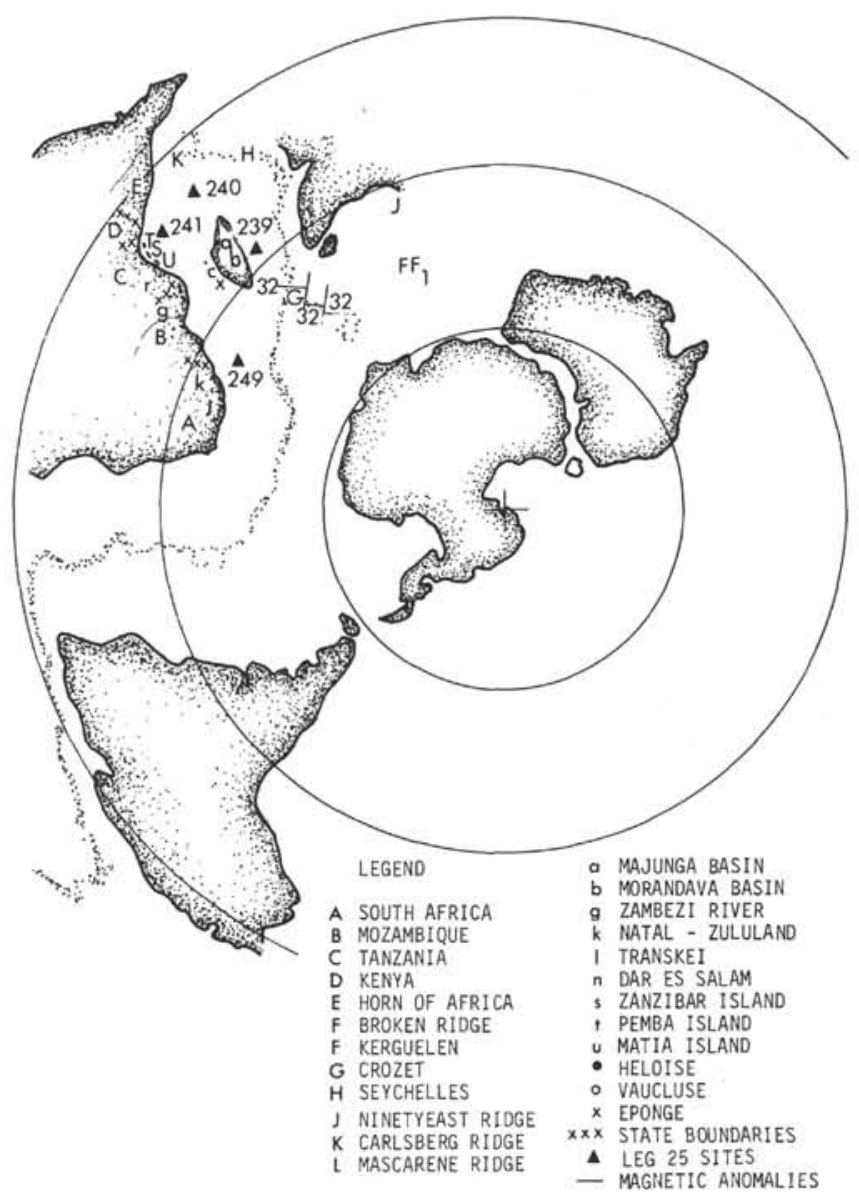

Figure 4. Approximately 75 m.y. ago reconstruction (late Senonian) (according to McKenzie and Sclater, 1971).

the Morondova Basin) of the Campanian can be singled out as a similarity.

Boreholes Hélö̈se and Eponge drilled by Compagnie Francaise des Pétroles extended the existence of a continuous series of marine deposits to the off shore realm in place of the hiatus at Site 249 . There are rhyolitic volcanic episodes, either before the Coniacian in Héloïse (middle Cretaceous? or Cenomano-Turonian) or in the Coniacian (Eponge). The third hole (Vaucluse) is somewhat comparable to Site 249 by its marine series being restricted to the Campanian-Maestrichtian. A thick (more than 1500 m) ignimbritic volcanic complex with very sparse marine beds occupies the position between this late Senonian and the middle Cretaceous.

Finally, it might be well to consider a comment made by Collignon on the presence of macrofauna with cold or boreal affinities (Nordenskjoldia and Buchia) in the Ambatry Maestrichtian south of the Onilahy River. It would be interesting to know whether the microfauna also have this same special feature and then to compare them with those at Site 249 and with the assemblages in the Majunga Basin, which are distinct. Also, the first of the two Ammonite genera mentioned above has also been found in the Grudja Formation in southern Mozambique.

\section{Comparison with the Mozambique Coastal Area}

The southern basin, which is geographically closer to Site 249 , reveals a quite different marine sequence. Toward 
Beira and the Zambezi River in the north, the sandy Sena facies probably reaches the Cenomanian-Turonian (pollen studies) and then the Senonian. Whereas in the south, toward Rio Save and offshore, the Turonian is probably attained by the Domo facies, which is more argillaceous and is considered to have euxinic influences, with some openly marine planktonic beds. Both of these facies, and the Domo earlier than the Sena, pass into the Grudja Formation, which is mainly sandy-glauconitic and has littoral to neritic facies where it crops out, but which was deposited toward the east in a deeper sea as shown in subsurface by the holes. This formation probably extends from the Santonian to the Paleocene (and even from the Coniacian in the subsurface).

The northern basin, on the contrary, reveals a biofacies (Globotruncana marls) which at first consideration might correlate with the one at Site 249, especially since it is dated in the Campanian and Maestrichtian after a hiatus lasting since the Albian. However, some details (e.g., these marls are gypsiferous) and the geographical remoteness hardly allow for anything more than a probable correlation to be made. Moreover, Flores (1972) interprets the stratigraphic hiatus here as being the result of a fault movement, with the missing stages occurring father north in Tanzania.

\section{Comparison with the E-SE Coastal Area of South Africa}

The Late Cretaceous is known from Natal to East London and from there to Agulhas Bank. Only Natal and northern Transkei are considered here; they are closer to Site 249. The marine series here is more complete than at Site 249. It is generally calcareous, sometimes sandy. A partial inventory of the microfauna has already been made for the late Senonian (Smitter, 1955; de Gasparris, 1968; and G. Lambert, 1970). It reveals a great many planktonic forms and several of the benthonic species found at Site 249. However, almost all the Late Cretaceous stages have been identified on the basis of macrofauna, beginning with the early Cenomanian. Perhaps the late Cenomanian and the Turonian are missing, and, in Natal, there is a transgression of the Coniacian onto the Aptian (and even of the Santonian on Ordovician sandstones). Could this be further evidence of the phenomena which are responsible for the large hiatus at Site 249?

To conclude, and continuing with the conclusion stated previously, it can be pointed out that the absence of data at the level of the Late Cretaceous, prior to the resumption of marine sedimentation in the Campanian, does not enable Site 249 to be compared with the coast of either Madagascar or Africa. It can be suspected that in all three places the stratigraphic sequences bear the mark of large-amplitude events from the Cenomanian to the Campanian-events which probably produced different effects. It must be admitted that the sequence at Site 249 is especially mute on this point.

In the Early and middle Cretaceous, some authors have opposed the African and Madagascar sides of the Mozambique Channel with regard to their behaviors (stress conditions of tension with volcanism in the west, compressional stress without volcanism in the east) during the drifting of Madagascar. With such a hypothesis, the volcanism at the bottom of Hole 249 would place this site to the west of the presumed dividing line. However, it is not possible to say whether it belonged to the Madagascar realm afterwards, during the elastic release and volcanic phase which apparently accompanied the relative immobilization of Madagascar in the Late Cretaceous.

\section{Late Cretaceous at Site 241}

A comparison will be made with deposits of the same age (early Senonian to Campanian followed by a hiatus before the Paleocene) in Kenya and Tanzania. On account of its remoteness, Site 241 suggests that differences of some importance may exist between it and the coastal fringe. However, this is not the only reason for the differences that were found.

Marine formations are known onshore throughout the entire Cretaceous. Diagrammatically, the Neocomian at its extreme bottom terminates the Jurassic sequence (shallow-water Ammonite deposits); then the Cretaceous sequence represents a period of regression compared with the Upper Jurassic and corresponds to continental (famous for their reptiles), estuarine to brackish deposits, and to limestones (Freretown) in which macrofauna and microfauna (benthonics, Orbitolina) have demonstrated the existence of the late Neocomian and the Barremo-Aptian. The marine realm asserts itself by a new transgressive movement in the Aptian and Albian, although it still remains neritic and sandy or even reefal. Mudstone and openly marine shale facies with pelagic microfauna take over beginning in the late Albian. It is obviously this Late Cretaceous which is of interest in a comparison with that at Site 241. However, a fundamental difference appears with relation to the biological content. The Late Cretaceous that is considered on land is Lamu Embayment in Kenya and the central (at the latitude of Dar es Salaam) and southern provinces in Tanzania (in the northern province it is apparently less abundant, probably partly because of outcropping conditions, under a Tertiary cover that shows a transgressive nature). It has been subdivided into its classic stages on the basis of planktonic microfauna from the Cenomanian to the Maestrichtian. Site 241 is thus in opposition because of its sparse, poor, and exclusively benthonic microfauna assemblages. The proposed interpretation is one of mixed assemblages wherein elements from the slope were carried off by turbidity currents into the bathyal realm. However, the absence of planktonic species is still unexplained, especially since the limestone nannoplankton remain present, although poor.

In places these onshore Late Cretaceous series reveal minor regressions with gaps or local unconformities (especially in the Cenomanian and Turonian, and between the Coniacian and Santonian) and with the development of more detrital facies and sometimes of faunal assemblages from the shallow continental shelf. The thick mainly turbiditic sequence at Site 241 thus did not develop under the same conditions which occurred contemporaneously nearer the continent in a marine environment that can be qualified as "subparalic" and in an edge-of-basin paleographic setting.

In Ethiopia and the Somalias (or the Horn of Africa), the Late Cretaceous belongs to an entirely different facies (biofacies with corals, Bryozoa, Rudistids, etc.). 
Now, the transition between the Cretaceous and the Tertiary can be compared with the one known in the southern province of Tanzania or on the islands (Zanzibar, Pemba, Mafia). This transition appears to be continuous there, with argillaceous deposits containing planktonic microfauna, sandstones or detrital or algal limestones.

To conclude, it is deceptive to search in the sequence at Site 241 for evidence of the instabilities mentioned in the outcropping series. The cores are too sparse; and above all, it is not very probable that any common point exists with regard to the depositional environments. However, the nannoplankton give a probable Campanian age for Core 22, which is separated from Core 21 by only 25 meters, with the foraminifers in the latter core suggesting a middle Paleocene age. But if the fact is taken into consideration that by going up less than 100 meters the boundary between the early and middle Eocene is attained, it is tempting to conclude that Site 241 contains a series that is reduced in thickness but is actually continuous just like the one in the southern province of Tanzania and yet is in a more pelagic realm.

\section{Terminal Cretaceous at Site 239}

The few tens of centimeters of Late Cretaceous age at Site 239 appear to be quite isolated in this general comparison. They reveal an unusual microfaunal assemblage that is quite different (by the benthonic species present and by the absence of planktonic species) from the one that is known either in the Majunga Basin or in the Diego region in Madagascar.

On the east coast of Madagascar (Figure 3), the Maestrichtian has been identified along a narrow coastal strip running from south of Tamatave to Mananjary (it is transgressive on basalts which up to now have been considered as the possible equivalents of Turonian basalts known farther north also on the east coast but which are in reality, partially at least, younger [measured age of about 75 m.y.]). The macrofauna suggest neritic conditions which, a priori, are not very compatible with a microfauna of the type found at Site 239. It is true, however, that the microfauna apparently have not been studied there. ${ }^{1}$

The possible oceanic nature of the basalt at Site 239, moreover, shows that there is very little logic in searching for features of comparison between the Cretaceous deposits it contains and those known onshore.

\section{Eocene at Sites 239 to 241 and in Northern Madagascar}

For discussions of the Eocene and Oligocene, refer to the regional reconstruction of the Indian Ocean as given in Figures 5 and 6. Diagrammatically, the Diego region (Diego Bay and Montagne des Français) reveals early Eocene and perhaps Paleocene dolomites with basaltic tuff, Ypresian Alveolina limestones, and sandy middle Eocene Nummulites limestones (perhaps attaining the late Eocene).

\footnotetext{
${ }^{1}$ When proofing the galleys, study of the microfauna was in progress by the author. Neritic benthonic foraminifera mixed with a few planktonics, forms a quite different assemblage from the one observed at Site 239. Moreover, its age is younger, i.e., late Maestrichtian.
}

The dolomites lie on top of Maestrichtian sands or Campanian marls. ${ }^{2}$

Hence, it is a different sequence from the one found at Site 239, with pelagic Danian and late Eocene. It is also different from the one at Holes 240 and 240A where the early Eocene, which was the only one recognized, is pelagic. It is tempting to make a comparison between the basalt from Site 240, in which sediment is included, and the basaltic tuffs from Diego, which reveal a calcareous pattern with macro- and microfauna. But this is certainly no more than a similarity, stemming from the identity of the (marine) depositional environment.

We have seen that Site 241 contains a sequence running from the Paleocene to the boundary between the early and middle Eocene and that this sequence developed under quite different conditions (turbidites, bathyal).

\section{Eocene at Site 241 and on the Coastline of Tanzania and Kenya}

At Site 241 we are confronted with a highly incomplete sequence. The bottom of the Paleocene is probably absent, and the early Eocene, or its boundary with the middle Eocene, is under the late Oligocene. Onshore it is difficult to find any points with very great resemblances.

In the southeast part of the Lamu Basin in Kenya, the semideltaic, semimarine Paleocene is followed by the calcareous and neritic early and middle Eocene and then by another very thin deltaic deposit with some neritic marine incursions up to the Oligocene.

In the northern province of Tanzania, the series is continental up to the Pliocene. In the central province, only the Paleocene is known (in coastal boreholes) and, if it is not actually reworked in the Miocene, its position is such that it might possibly be compared with the Eocene at Site 241. Its relations with the Cretaceous are not known, but the Cretaceous is overlain by the Neogene in other boreholes.

If the islands are considered, however, a greater similarity between Site 241 and what is known from drilling there might be found. For example, on the island of Zanzibar, the Eocene sequence is truncated in a somewhat similar way at the level of the middle Eocene. In addition, the interbedding of neritic sediments (Nummulites and Alveolina limestones, etc.) reveals a quite different depositional environment.

Hence we return to the restraints already mentioned in relation to the Late Cretaceous-a restraint which has a paleogeographic nature.

At the level of the upper part of the Paleogene sequence, a common feature can be pointed out, but it concerns the problem of the "Oligocene hiatus" and the "Miocene transgression" (late Oligocene at Site 241) which will be examined later. On land, the Miocene overlies the entire sequence up to the Jurassic, and the Paleogene sequence is always (except southeast of Lamu embayment) truncated

\footnotetext{
${ }^{2}$ At the time of writing this chapter, a recent very detailed thesis on the northernmost part of Madagascar was not known by the author (see Karche in the selected references).
} 


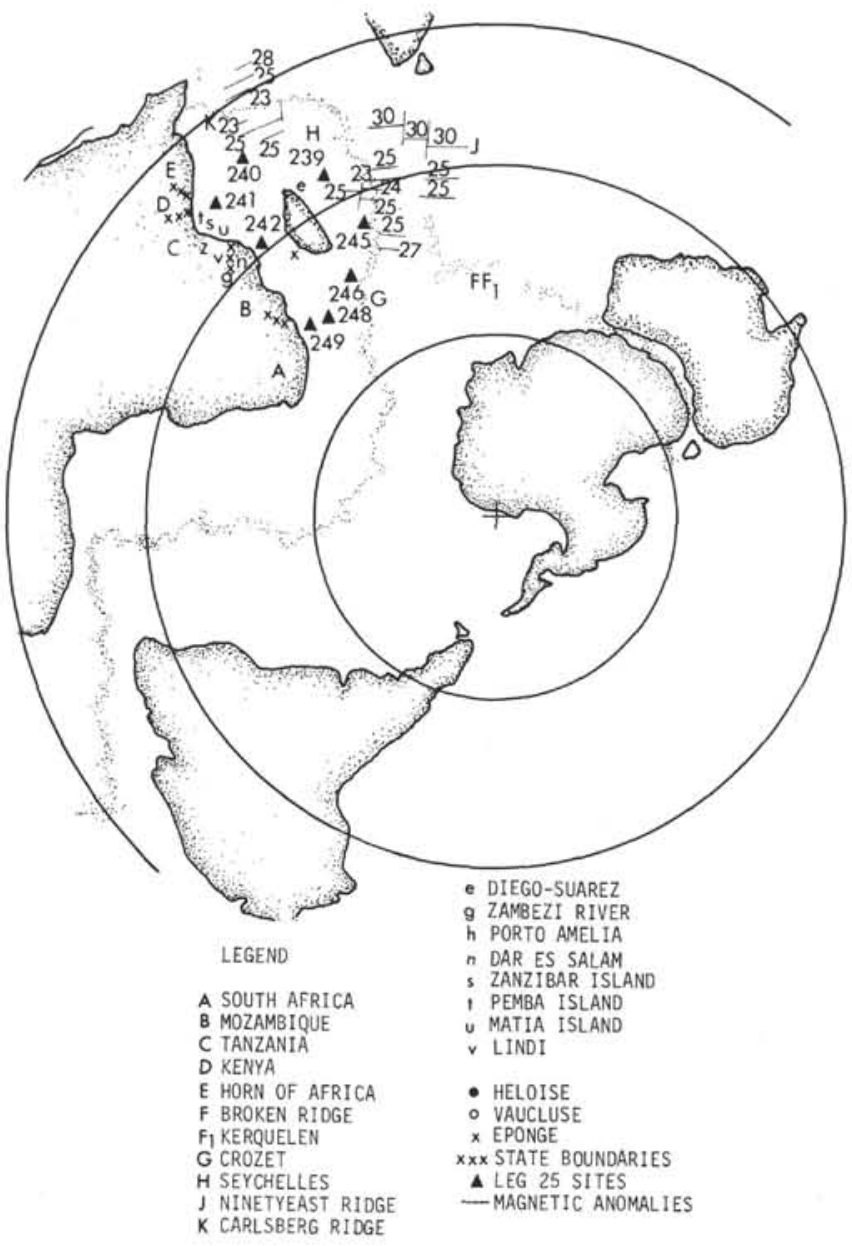

Figure 5. Approximately 45 m.y. ago reconstruction (late Eocene) (according to McKenzie and Sclater, 1971).

at different levels. Only the boreholes on the other islands (Pemba, Mafia) revealed, as in Lamu embayment, late Eocene and Oligocene strata. But with regard to the Oligocene, it should be mentioned that accessible data do not enable the age to be determined with sufficient accuracy to allow making a reliable comparison with a late Oligocene deposit which might actually be linked to the transgressive Neogene cycle, as is perhaps the case on Lamu and also, in my opinion, at Site 241 (concerning this, Eames et al., 1962, have already pointed out that no late Oligocene-Chattian would be found in East Africa). Nonetheless, it is a fact that the pelagic late Oligocene at Site 241 is very different from the shallow littoral "regressive" facies known onshore (in Lamu and on the islands of Zanzibar and Pemba, some deltaic influences even appear).

\section{Continuous Late Eocene-Oligocene at Site 242}

The continuous Paleogene sequence found beginning at the bottom of the late Eocene should be compared with both Mozambique and Tanzania, with special attention being paid to the Oligocene and the boundary with the Miocene.

\section{Comparison with the Mozambique Coastal Area}

Onshore, as in the coastal subsurface, this upper part of the Paleogene seems quite different. However, it appears to begin to reveal some similarities because of the effect of rapid lateral variations in the eastward-trending facies. The Paleocene and Eocene either lie in depositional continuity on top of the late Senonian (Grudja Formation in the southern basin), or else occur in the form of neritic sandy limestones as it concerns the Paleocene (northern basin), and then in the form of nummulitic and algal carbonate deposits, which apparently includes the Eocene (sometimes with exception of its base). An area of some similarity with Site 242 is the Porto Amelia region in the northern basin where marls and planktonic marly limestones are found (the early to middle Eocene here can be suspected because Globorotalia aragonensis is referred to in the literature for that region) and are described as "continuing into the Oligocene." This is possibly already the beginning of what will be found to be firmly established in Tanzania. But the Miocene here is unconformable, and the similarity goes no further with regard to the outcrops.

As a general rule, the Oligocene actually shows a regression phase (decrease in thickness in the coastal boreholes and evaporitic facies even locally at the end of the Oligocene at the mouth of Rio Save). However, another point of comparison with Site 242 lies in the fact that going eastward in the coastal boreholes in the southern basin a thick Oligocene-Miocene marine sequence is encountered which is still neritic (with Lepidocyclina, Miogypsina, Spiroclypeus, etc.) but is often rich in planktonic species (Mongue limestone, Jofane Formation, Inharrime Formation-with the last one reported as going from the middle Eocene to the middle Miocene). Hence on a large scale, we can suspect that in the west, the Miocene should prove to be unconformable and transgressive with continental to brackish sediments, and that to the east, on the contrary, it should change to shallow-marine sequences but already with some pelagic influence, which had begun in the Oligocene at least.

\section{Comparison with Tanzania (Lindi Area)}

In this extreme southern part of Tanzania, the Paleogene is, generally speaking, in continuity with, or sometimes in slight unconformity on, the Late Cretaceous. From the stratigraphic standpoint, this results in the simultaneous development of clays, silts or marls, and neritic limestones. Consequently, the small foraminifera (especially planktonic species) and larger foraminifera can be analyzed together, and they make this region into one that is used as a reference for the zonation of these levels (Eames et al., 1962). The Paleogene thus probably corresponds to a deposit on a slowly sinking but relatively stable continental shelf. The late Eocene is characterized by sediment deposited in shallower water (a phenomenon that began in the middle Eocene) with more abundant neritic-fauna limestones, which precedes the maximum regression of the Oligocene (the Chattian is even sometimes absent). The Miocene transgression occurred in a shallow clastic or reefal environment.

To conclude, although located at a distance and offshore from the littoral fringes of Mozambique and Tanzania, Site 


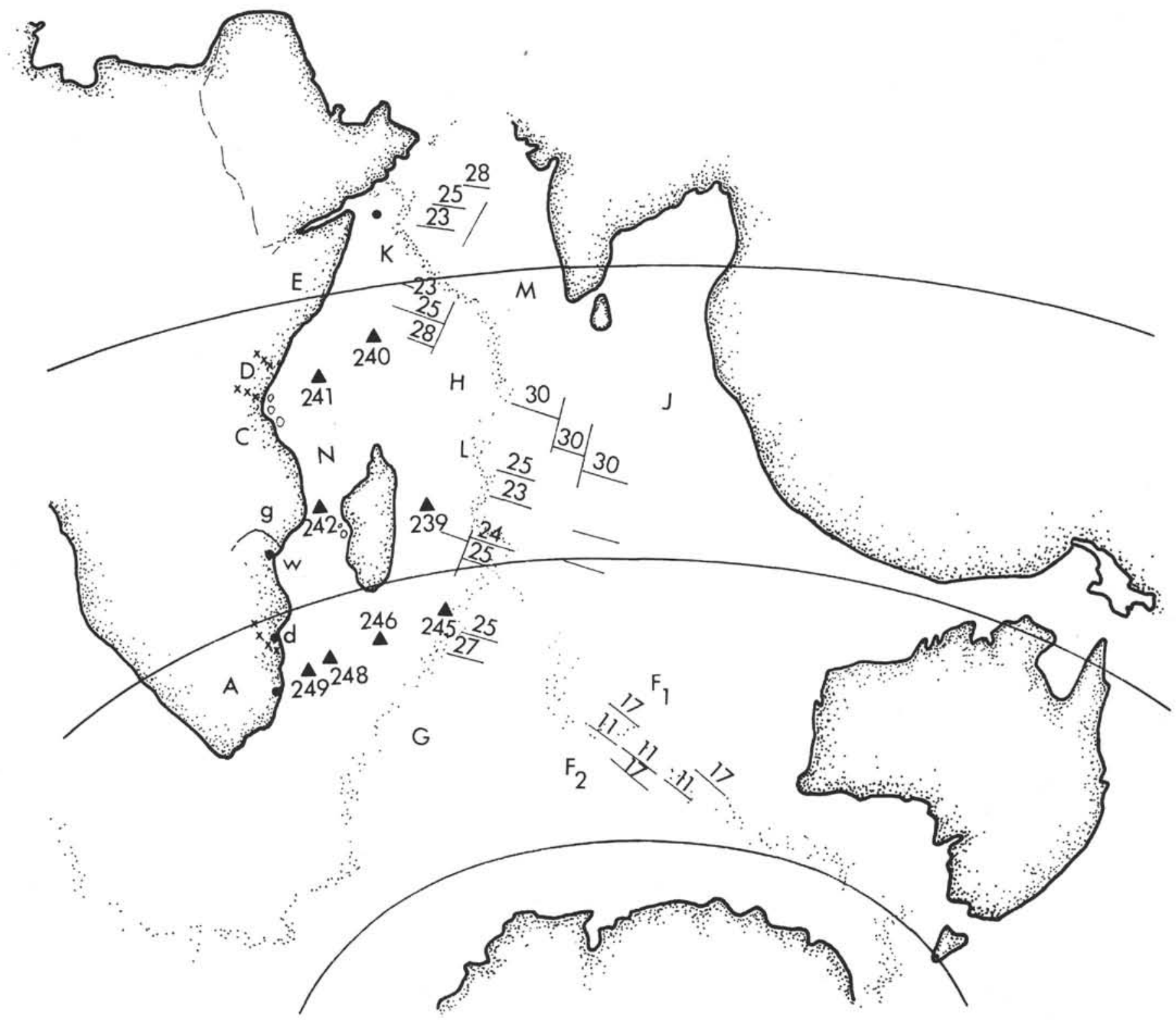

\section{LEGEND}
A SOUTH AFRICA
B MOZAMBIQUE
C TANZUNIA
D KENYA
E HORN OF AFRICA
$F_{1}$ BROKEN RIDGE

G CROZET

H SEYCHELLES

J NINETYEAST RIDGE

$K$ CARLSBERG RIDGE

L MASCARENE RIDGE

M MALDIVE-LACADIVE ISLANDS

$N$ COMORO ISLANDS

- HELOSIE
- VAUCLUSE
$\times$ EPONGE
a MAJUNGA BASIN
b MORANDAVA BASIN
d LOURENCO MARQUES
g ZAMBEZI RIVER
i DURBAN

s ZANZIBAR ISLAND
+ PEMBA ISLAND
UMAFIA ISLAND
WBEIRA
- MAGNETIC. ANOMALIES
M LEG 25 SITES
$\times \times \times$ STATE BOUNDARIES

Figure 6. Approximately 36 m.y. ago reconstruction (early Oligocene) (according to McKenzie and Sclater, 1971). 
242 is indeed located in the above described setting. This setting has the singularity of having quasi-continuous or continuous sedimentation in the east between the Eocene and the Miocene, or at least a tendency toward being such a comprehensive series. This is opposite to what is found farther west in the same littoral fringes, i.e., a lateral variation toward continental sediments with a reduction in, or even an absence of, deposition. However, because it is even farther offshore, the sequence at Site 242 proves to be still more pelagic and appears more complete (to the extent that this is revealed by the cores). It is quite possible that the regression, and even the Oligocene hiatus and the Miocene transgression, are not recorded at Site 242.

The few indications previously given on the nature of the Eocene deposits onshore suggest what the borehole might have found had it gone deeper than the expected acoustic "basement", which in reality proved to be a level showing an abrupt variation in some physical properties of the sediment.

\section{Comparison with the West Coast of Madagascar}

In the same way as before, a comparison with the coast of Madagascar (Figure 3) at the latitude of the Morondava Basin, as well as with the Compagnie Francaise des Pétroles offshore boreholes, shows that deeper down a fairly complete series might have been expected going from the late Lutetian to the Danian (in the Majunga Basin in the Antonibe region there are even levels from the base of the late Eocene). This occurs lithologically and biologically in the form of alternating marls and limestones, sandstones or dolomites, with pelagic or neritic fauna, depending on the case.

On the other hand, the late Eocene-Oligocene sequence at Site 242 is not represented onshore except by the highly limited and isolated case of the neritic Stampian on the island of Nosy Kalakajoro (north of the Majunga Basin) which is a level that in reality we assume to be linked to the so-called Miocene transgression. ${ }^{3}$

In the coastal boreholes in the Morondava Basin (Andravadoaka) and expecially in the C.F.P. offshore holes, the late Paleogene series occur. They are the same ones missing from the outcrops, and they are also the time equivalents of the strata crossed through at Site 242 . Offshore from Madagascar, these sediments are part of a thick sequence which developed after the Late Cretaceous in a neritic or platform facies (in particular with larger foraminifera) but in which the pelagic microfossils, especially in the late Paleogene, enable a good stratigraphic parallelism with Site 242 . Laterally, similar to what happened along the African coast, but here in an eastward direction, a hiatus onshore represents the marine formations developed offshore.

\section{Neritic Eocene at Site 246}

The early Eocene deposits at Site 246 are made conspicuous by their clastic and biodetritic assemblages. They should be compared with relatively similar ones found

\footnotetext{
${ }^{3}$ This could be tested in the future through biometric examinations of the lepidocyclina in the light of recent studies (see Beratti in the selected references).
}

in outcrops or in shallow boreholes in extreme southern Madagascar between the Menarandra River and Cap Sainte Marie in the form of Alveolina limestones. These limestones, moreover, are related to Ypresian Alveolina and Nummulites limestones, known the entire length of the Morondava Basin, at least up the Mangoky River, where they form the bottom of a series which is completed upward by an early and middle Lutetian.

At Site 246, just as onshore, the "Paleogene" hiatus occurs, but above this, the transgressive deposits are quite different even though they are roughly of the same age. At Site 246, the deposits are clastic and biodetritic but with a few planktonic species more or less characteristic of the Oligocene-Miocene boundary. Onshore, on the contrary, the facies are lagoonal or gypsiferous overlain by layers containing oysters and Cyphus attributed to the "Aquitano-Burdigalian", in places with brackish or lagoonal foraminifera and ostracods.

It is of interest to again mention the fact that a coastal borehole in the Morondava Basin between the Mangoky and Onilahy rivers (Andravadoaka) reveals a Lepidocyclina and Miogypsina-bearing neritic Oligocene and a Miogypsinabearing "Aquitano-Burdigalian."

What might have been found at Site 246 under the early Eocene if weather and technical conditions had not made it impossible to continue drilling? Continuing the analogy with the southern part of the island, there are several possibilities. These are the following: (1) a basalt considered to be of Campanian age, (2) sandstones and marls from the "Terminal Cretaceous" and the continental Santonian (like the one found in a shallow onshore borehole), or (3) a crystalline basement overlain by undated clays (Cretaceous?) like in the borehole at Saraondry in the gravimetric "trough" bearing the same name. Nevertheless, it must be kept in mind that the past evolution, before Eocene time, could have been much different.

Before concluding, it should be added that the neritic-facies Eocene limestones with Nummulites and Discocyclinids are also known on the African coast; but their age is different, being either middle Eocene (northern basin in Mozambique) or late Eocene (northern basin in Mozambique, and Bathurst-Alexandria Formation in South Africa). The age of the latter formation, moreover, is questionable because the rich assemblage, which is actually of early to middle Eocene age, was reworked in an extremely littoral Miocene with very little fossil evidence (Bourdon and Magnier, 1969).

\section{The Oligocene Hiatus and the Miocene Transgression}

As can be seen in the figure comparing the different sites (Figure 1), this hiatus and transgression are common to several sites. These events are already well known both onshore and offshore where they indicate a gap in the stratigraphic column, roughly at the level of the Oligocene, followed by a resumption of sedimentation lasting roughly from the middle Oligocene to the early Miocene. This phenomenon is striking because of its worldwide extension. It occurs on ridges as well as in the neighboring basins, but detecting it is difficult, and it is quite probable that there are several causes underlying it.

On the same figure (Figure 1) it can be seen that at least one site is an exception to this. It also has been noted that 
the one site is located in a certain regional setting where marine sedimentation persists during the interval being considered.

This setting includes the extreme southern part of Tanzania, perhaps a very limited area in the northern basin in Mozambique, and two other regions also in Mozambique (one around Beira and the Zambezi delta, and the other running toward Lourenço Marques). The coastal fringe clearly shows the regressive nature or the absence of the Oligocene and the transgressive nature of the Miocene (in the continental series, the Oligocene cannot always be separated from the Miocene). However, farther east the series is completed and becomes more neritic, then more pelagic, with the hiatus always remaining perceptible. Site 242 is located within this setting of a continuoussedimentation area which is far enough offshore for deposition to take place in a more pelagic facies.

A parallel situation is found on the coast of Madagascar where there are gypsums and lagoonal deposits overlain by Aquitano-Burdigalian oyster layers. However, neritic deposits of the same age and with larger foraminifera appear in the coastal boreholes; the series then is perhaps continuous since the Paleogene with pelagic-fauna beds interspersed in the midst of neritic (if not reefal or lagoonal) deposits in the offshore boreholes.

This exceptional area is bounded, to a certain extent, by regions in which the "Oligocene hiatus," in outcrops as in the subsurface, is, on the contrary, an important event in the stratigraphic column. In this context, another regional setting takes shape, and such Sites as 240, 241, 246, 248, and 249 can be situated in it. These "hiatuses" (if any) are discussed and analyzed by Leclaire (this volume).

Reference has already been made to each of these sites in the preceding sections in an attempt to compare them with data known from Kenya, Tanzania, Mozambique, and Madagascar. Moreover, it has been reported that some deposits attributed to the late Oligocene are in reality quite probably linked to the transgressive cycle. For example, this is the case for Site 242. Actually, the accessible faunal data do not enable one to reach the same conclusion for various deposits observed onshore or in the subsurface (Oligocene in Lamu Basin, Stampian on the island of Nosy Kalakajoro in the northern part of the Majunga basin, Oligocene in boreholes on the islands of Mafia and Pemba, which instead might correspond to a temporary continuation of sedimentation after the Eocene, like at Lindi). The investigations still remaining to be done will be great value for advancing along the path opened up by Eames et al. (1962) on the possible absence of the late Oligocene in East Africa. The example of Site 241 shows that a detailed analysis can be used for the accurate dating of the resumption of sedimentation or transgression which, up to now, has traditionally been qualified as "Miocene" or "Aquitanian"

As we reported earlier, the contact surface cuts across a great variety of ages all the way to the Jurassic, the Karroo, or the basement. At Site 249, it is the Maestrichtian which terminates the pre-Miocene sequence (in which Paleocene has been reworked) as it does in Zululand in southern Mozambique, where the neritic early Miocene sometimes actually lies on top of the Late Creatceous Grudja Formation.
In the stratigraphic profiles (in boreholes, in general) where the gap is found above a series that is still Eocene, it is mainly the Late Eocene and the Oligocene which are missing. However, in places the late Eocene remains, and perhaps even the Oligocene (provided that, in the islands of Pemba and Mafia, the Oligocene that is mentioned is effectively linked to the Paleogene cycle and not to the transgression). On the contrary, it is sometimes the middle Eocene which underlies the Miocene (e.g., in the Morondava and Majunga basins as well as at Site 241), or even the early Eocene (extreme southern part of Madagascar and Site 246, as might "paleogeographically" be expected; and Holes 240-240A). The problem of Site 248 cannot be solved for the time being because of the lack of accurate data on the ages (nevertheless, the first data provided by studies of Radiolaria suggest a wide hiatus, possibly covering middle Eocene, late Eocene, and the Oligocene).

The nature of the deposit itself is quite striking. It is true that the "transgressive" neritic or littoral nature is more highly accentuated in the outcrops on the sedimentary fringes of the African and Madagascar coasts. But, as a general rule, this nature is extremely marked, not only in the coastal boreholes but also in the sites on Leg 25, and this is true despite the undeniable pelagic influence. The sediments in the sites have abundant sandy residue, littoral and even reefal benthonic fauna (in particular Bryozoa, Balanids, and larger foraminifera), and show evidence of reworking of the older strata. The transport by turbidity currents obviously provides an explanation in some levels, but one which does not fit all cases.

The different setting for Site 242 has been point out. Nonetheless, there is like a "gap" in the way the tests are preserved: because the Miocene shows the effects of dissolution and/or pressure while the Oligocene contains well-preserved fossils. Site 239 also stands out because between Cores 14 and 13 there does not appear to be any appreciable lithological change. Since these two cores are relatively far apart, the question arises as to whether sedimentation was not more or less continuous between the terminal Eocene (14) and the late Oligocene (13). However, this probably took place in an entirely different realm (oceanic?) from that of the continuous sedimentation area that has been centered around Site 242 . Site 245 is entirely apart since different bathymetric conditions are probably responsible for the facies change affecting the middle and late Eocene. We must nonetheless accept: (1) that the Oligocene was not preserved there and (2) that, if the middle Miocene exists, it is in the form of an argillaceous sediment with a completely different nature from the underlying levels. It should be borne in mind that this site lies on a magnetic anomaly and that it has undergone the fate reserved for a piece of the ocean-bottom that has been subjected to lateral drift starting from the Southeast Indian Ridge, as well as to continuous deepening.

A similar hiatus (called "paraconformity") has been found in an oceanic area not too far away, i.e., in the vicinity of southern Australia and New Zealand by exploration during Leg 21. On this subject, various authors (Kennett et al., 1972; Carter and Landis, 1972) have spoken of erosion by vast and powerful movements of masses of water. This "erosive" paleo-circulation has been 
attributed both to antarctic glacial history (linked to the general cooling in the late Eocene-Oligocene) and to the drift of the Australian continent (opening up a circum-Antarctic gap). Either or both of these phenomena might have contributed to the setting in motion of enormous cold water masses along the paths of new currents, thus producing changes at great depths and on a vast scale.

Of course, it is not necessary to go so far away to look for close analogies in order to understand what has happened at the sites in the southwestern part of the Indian Ocean. However, from the latitude of Site 245, we can already infer that it may have been affected by phenomena that are genetically linked to what was taking place farther east. Also, it is quite possible that among similar paleoclimatological and/or paleotectonic phenomena we might find an explanation of the "anomalies" in the stratigraphic columns of the different sites in Leg 25 .

\section{BIBLIOGRAPHY OF SELECTED REFERENCES}

(References marked with an asterisk are referenced [author, year] in the preceding text of this chapter, others are not.)

\section{General Geology}

*Blant, G., 1973. Structure et paléogéographie du littoral méridional et oriental de l'Afrique. In Bassins sédim. Littoral Africain, Pt. 2. Littor. austral et orient.: ICG C. African Symposium, 24th, Montréal, 1972. Paris (Assoc. African Geol. Surveys) p. 193-234.

*Carter, R. M. and Landis, C. A., 1972. Correlative Oligocene unconformities in southern Australasia: Nature, v. 237, p. 12-13.

Flores, G, 1970. Suggested origin of the Mozambique Channel: Geol. Soc. S. Afr. Trans., v. 63, p. 1-16, and p. 109-110.

*Kennett, J. P., Burns, R. E., Andrew, J. E., Churkin, M., Davies, T. A., Dumitrica, P., Edwards, A. R., Galehouse, J. S., Packam, G. H., and van der Linden, G. J., 1972. Australian-Antarctic continental drift, paleocirculation changes and Oligocene deep-sea erosion: Nature, v. 239 , p. 51-55.

Kent, P. E., 1972. Mesozoic history of the east coast of Africa: Nature, v. 238, p. 147-148.

Maack, R., 1969. Kontinental Drift und Geologie des Sudatlantischen Oceans: Berlin (W. De Gruyter \& Co.).

McKenzie, D. and Sclater, J. G., 1971. The evolution of the Indian Ocean since Late Cretaceous: Roy. Astro. Soc. Geophys. J., v. 24, 92 p.

\section{Regional Geology}

\section{Horn of Africa}

Beltrandi, M. D. and Pyre, A., 1973. Geological evolution of southwest Somali. In Blant, G. (Ed.) Bassins Sédim. Littoral Africain, Pt. 2. Littor, austral et orient:, IGC E. African Symposium, 24th, Montréal, 1972. Paris (Assoc. African Geol. Surveys) p. 159-178.

Mohr, P. A., 1960. The geology of Ethiopia: (Univ. College of Addis-Ababa), $268 \mathrm{pp}$.

\section{Kenya}

Walters, R. and Linton, R. E., 1973. The sedimentary basin of coastal Kenya. In Blant, G. (Ed.) Bassins Sédim.
Littoral Africain, Pt. 2. Littor. austral et orient.: IGC E. African Symposium, 24th, Montréal, 1972. Paris (Assoc. African Geol. Surveys) p. 133-158.

\section{Madagascar}

Andriamirado, C. A. R., 1971. Recherches paleomagnétiques sur Madagascar. Résultats et interprétations dans le cadre de la discolation de la partie orientale du Gondwana: Thesis, Univ. Louis Pasteur, Strasbourg.

Besairie, H., avec la collaboration de M. Collignon, 1972. Géologie de Madagascar. I. Les terrains sédimentaires: Ann. Géol. de Madagascar, pt. 35, 463 pp.

Brasseur, R., Godard, J. M., Guérin-Desjardins, B., Hindermeyer, J., and Rebilly, G., 1959. Pré-reconnaissance petroliére du bassin de Majunga (Madagascar): Rev. Inst. France. Pétrole, v. 14, p. 3-16.

Colin, F., 1969. L'histoire du volcanisme en Afrique et à Madagascar du Mésozoïque au Quaternaire: essai de rècaptilulation. Ann Fac. Sci. Abidjan, p. 99-140.

Dixey, F., 1960. The geology and geomorphology of Madagascar, a comparison with eastern Africa: Geol. Soc. London Quart. J,, v. 116, p. 255-268.

Karche, J. P., 1972. Contribution a L'etude géologique de la Montagne d'Ambre et des règions voisines du Nord de Madagascar: Thèse, Université de Besancon, France.

\section{Mozambique}

Flores, G., 1964. On the age of Lupata rocks, lower Zambezi river, Mozambique: Geol. Soc. S. Africa Trans., v. 67.

*Flores, G., 1972. The Cretaceous and Tertiary sedimentary basins of Mozambique and Zululand. In Blant, G. (Ed.) Bassins Sédim. Littoral Africain, Pt. 2,. Littor. austral et orient.: IGC E. African Symposium, 24th, Montréal, 1972. Paris (Assoc. African Geol. Surveys) p. 81-111.

\section{South Africa}

Dingle, R. V. 1970. Preliminary geological map of part of the eastern Agulhas Bank, South-African continental margin: Geol. Soc. London, Proc. v. 1663, p. 137-142.

Dingle, R. V., Gerrard, I., Gentle, R. I., and Simpson, E.S.W., 1971. The continental shelf between Cape Town and Cape Agulhas. In The Geology of E.-Atlantic continental margin, Pt. 4, Africa: Sci. Comm. Oceanic Res. Symposium, Cambridge 1970, p. 199-209.

*Dingle, R. V. and Klinger, H. C., 1971. Significance of Upper Jurassic sediments in the Krysna outlier (Cape Province) for timing of the breakup of Gondwanaland: Nature v. 232, p. 37-38. (Also see Nature, v. 235, p. 59-61, for discussion by J. G. Jones and reply by R. V. Dingle.)

Jones, J. G., 1972. Significance of Upper Jurassic sediments in the Knysna outlier (Cape Province): Nature, Phys. Sc., v. 235 , p. 59-60.

Kennedy, W. J. and Klinger, H. C., 1971. A major intraCretaceous unconformity in eastern South Africa: Geol. Soc. London J., v. 127, p. 183-186.

Leyden, R., Ewing, M., and Simpson, E. S. W., 1971. Geophysical reconnaissance on African shelf. I. Cape Town to East London: Am. Assoc. Petrol. Geol. Bull., v. 55, p. 651-657.

Ruddock, A., 1973. The Tertiary limestones of the southern coastal regions of Cape Province, S. Africa. In Blant, G. (Ed.) Bassins Sédim. Littoral Africain, Pt. 2. Littor. austral et orient.: IGC E. African Symposium, 24th, Montréal, 1972. Paris (Assoc. African Geol. Surveys) p. 49-62. 
Simpson, E. S. W. and Dingle, R. V., 1973. Offshore sedimentary basins on the southeastern continental margin of South Africa. In Blant, G. (Ed.) Bassins Sédim. Littoral Africain, Pt. 2. Littoral austral et orient.: IGC E. African Symposium, 24th, Montréal, 1972. Paris (Assoc. African Geol. Surveys) p. 63-67.

van Hoepen, E. C. N., 1929. The Cretaceous beds of Zululand: Internatl. Geol. Congr., 15 Session, Guide Book, Excursion C, p. 10-18.

Winter, H. de la R., 1973. Geology of the Algoa basin, South Africa. In Blant, G. (Ed.) Bassins Sédim. Littoral Africain, Pt. 2. Littoral austral et orient.:, IGC E. African Symposium, 24th, Montréal, 1972. Paris (Assoc. African Geol. Surveys) p. 17-48.

\section{Tanzania}

*Eames, F. E., Banner, F. T., Blow, W. H., and Clarke, W. J., 1962. Fundamental of Mid-Tertiary stratigraphical correlation. Pt. 2-3. The Tanganyikan Middle Tertiary (Upper Eocene to Lower Miocene): Cambridge, England (Cambridge University Press), p. 62-69.

Kent, P. E., Hunt, J. A., and Johnstone, D. W., 1971. The geology and geophysics of coastal Tanzania: Inst. Geol. Sc., Environment. Res. Council, London, Geophys. Paper, 6, $101 \mathrm{pp}$.

Kent, P. E., O'B. Perry, J. T., 1972. The development of the Indian Ocean margin in Tanzania. In Blant, G. (Ed.) Bassins Sédim. Littoral Africain, Pt. 2. Littoral austral et orient: IGC E. African Symposium, 24th, Montréal, 1972. Paris (Assoc. African Geol. Surveys) p. 113-131. Quennel, A. M., McKinlay, A. C. M., and Aitken, W. G., 1956. Summary of the Geology of Tanganyika: Pt. I Mem. Geol. Surv., Tanganyika, 264 pp.

\section{Africa (general)}

Furon, R., 1968. Géologie de l'Afrique: Paris (Payot), 374 pp.

Haughton, S. H., 1963. The stratigraphic history of Africa, south of the Sahara: Edinburgh and London (Oliver and Boyd), 365 pp.

Lexique Stratigraphique International, v. IV, Afrique. 1969. Geological history of southern Africa: Johannesburg (Geol. Soc. S. Africa), 535 pp.

\section{Micropaleontology}

Beretti, Annie, 1973. Recherches biométriques sur les Lépidocyclines du Nord de Madagscar: Thèse, $3^{\circ}$ Cycle, Université Paris VI.

*Bourdon, M. and Magnier, Ph., 1969. Notes on the Tertiary fossils at Birbury, Cape Province: Geol. Soc. S. Africa Trans., v. 72, p. 123-125.

Chapman, F., 1904. Foraminifera and Ostracoda from the Cretaceous of East Pondoland, South Africa: Ann. S. Africa Mus., v. 4, p. 221-237.

Collignon, M. and Sigal, J., 1955. Première note sur quelques Foraminiféres du Crétacé supérieur de
Madagascar: CR. Somm. Soc. Géol. France, v. 13, p. 291-292.

Davey, R. J. and Anderson, J. M., 1970. Micropaleontology in the search for oil in South Africa: S. Afr. J. Sci., p. 340-348.

Dingle, R. V., 1969. Marine Neocomian Ostracoda from South Africa: Roy. Soc. S. Africa Trans., v. 38, p. 139-163.

1969. Upper Senonian Ostracods from the coast of Pondoland: Roy. Soc. S. Africa Trans., v. 38, p. 347-385.

1971. Some Cretaceous ostracodal assemblages from the Agulhas Bank (South African continental margin): Roy. Soc. S. Africa Trans., v. 39, p. 393-418.

Éspitalié, J. and Sigal, J., 1963. Contribution à l'étude des Foraminifères du Jurassique supérieur et du Néocomien du bassin de Majunga: Ann. Géol. Madagascar, v. 32, 100 pp.

*de Gasparris, M. L., 1968. The microstratigraphy of the Cretaceous system of Zululand: Thesis, University of Witwatersrand, $136 \mathrm{pp}$.

Grekoff, N., 1963. Contribution à l'étude des Ostracodes du Mésozoïque moyen (Bathonien-Valanginien) du bassin de Majunga, Madagascar: Rev. Inst. Franç. Pétrol., v. 18 , p. $1709-1762$.

Herman, Y., 1963. Cretaceous, Paleocene and Pleistocene sediments from the Indian Ocean: Science, v. 140, p. 1316-1317.

*Lambert, G., 1970. A study of the Cretaceous foraminifera from northern Zululand: M. Sc. Thesis, University of Natal, Durban, 375 pp.

Lys, M., 1960. La limite Crétacé-Tertiaire et l'Éocène inférieur dans le bassin de Majunga:Internatl. Geol.Cong., v. 21 , pt. 5 , p. $120-130$.

Saito, T. and Feray, Ch., 1964. Cretaceous and Tertiary sediments from the southwestern Indian ocean (abs.): Geol. Soc. Am., Spec. Pap., 82, p. 171-172.

Sigal, J., 1954. Notes micropaléontologiques malgaches. 2. Microfaunes albiennes et cénomaniennes: CR. Somm. Soc. Géol. France, v. 12.

*Sigal, J., Grekoff, N., Singh, N. P., Cañon, A., and Ernst, M., 1970. Sur l'âge et les affinités "gondwanniennes" de microfaunes (Foraminifères et Ostracodes) malgaches, indiennes et chiliennes au sommet du Jurassique et à la base du Crétacé: CR Acad. Sci., v. 271, p. 24-27.

*Smitter, Y. H., 1955. Foraminifera from the Upper Cretaceous beds occurring near the Itongazi River, Natal: Paleontol. Africana, v. 3, p. 103-107. 1957. Upper Cretaceous foraminifera from Sandy Point, St. Lucia bay, Zululand: S. Africa. J. Sci., v. 53, p. 195-201.

1957. The species relationships and stratigraphic distribution of southern African Upper Cretaceous Epistomina: Paleontol. Africana, v. 5, p. 83-85.

*Wachendorf, H., Bettenstaedt, F., and Ernst, G., 1967. Zur Unter-Kreide Stratigraphie von Sud-Moçambique: N. Jb. Geol. Paleont., Abhandl., v. 120, p. 272-303. 



\section{PLATE 1}

\section{Cretaceous}

(Foraminifera: $\mathrm{a}=$ spiral view; $\mathrm{b}=$ umbilical view; $\mathrm{c}=$ edge view. Stereoscan illustrations, Laboratoire de Géologie, Muséum National d'Histoire Naturelle, Paris)

Figure 1 Cytheropteron sp. (a) Lateral view, $\times 90$ and (b) Dorsal view, X95. Sample 249-27-3, $125 \mathrm{~cm}$; Neocomian; same exemplar.

Figure 2 Cytherella sp. 1. (a) Right valve, internal view, $\times 60$ and (b) Dorsal view, $\times 65$. Sample 249-27-3, $125 \mathrm{~cm}$; Neocomian.

Figure 3 Cytherella sp. 2. (a) lateral view, $X 60$ and (b) Dorsal view, X65. Sample 249-27-3, $125 \mathrm{~cm}$; Neocomian; same exemplar.

Figure 4

Majungaella nematis Grekoff, 1963. (a) Lateral view, $X 50$ and (b) Dorsal view, X65. Sample 249-27-3, 26 $\mathrm{cm}$; Neocomian; same exemplar.

Figure $5 \quad$ Cytherella sp. 3. (a) Lateral view, $X 60$ and (b) Dorsal view, X70. Sample 249-26-I, $40 \mathrm{~cm}$; early Aptian or Barrëmian; same exemplar.

Figure 6 Amphicytherura(Sondagella) cf. theloides Dingle, 1969. (a) Lateral view, with broken posterior extremity, $\times 115$ and (b) Dorsal view of right valve, X115. Sample 249-26-I, $40 \mathrm{~cm}$; early Aptian or Barremian; same exemplar.

Figure 7

Ticinella sp. Same exemplar, (a) and (b), $\times 125$.

Sample 249-23-3, $3 \mathrm{~cm}$; late Albian or early Cenomanian.

Figure 8 Rotalipora balernaensis Gandolfi, 1957. Same exemplar, (a) and (b), X125. Sample 249-23-3, $3 \mathrm{~cm}$; late Albian or early Cenomanian.

Figure 9 Hedbergella modesta Bolli, 1959. (a) and (b), X165, (c) $\times 160$. Sample $249-23-3,3 \mathrm{~cm}$; late Albian or early Cenomanian; same exemplar for (b) and (c).

Figure 10 Hedbergella del rioensis (Carsey, 1926). (a) $\times 170$, (b) $\times 165$ and (c) $\times 160$. Sample 249-23-3, $3 \mathrm{~cm}$; late Albian or early Cenomanian; same exemplar for (b) and (c). 
PLATE 1
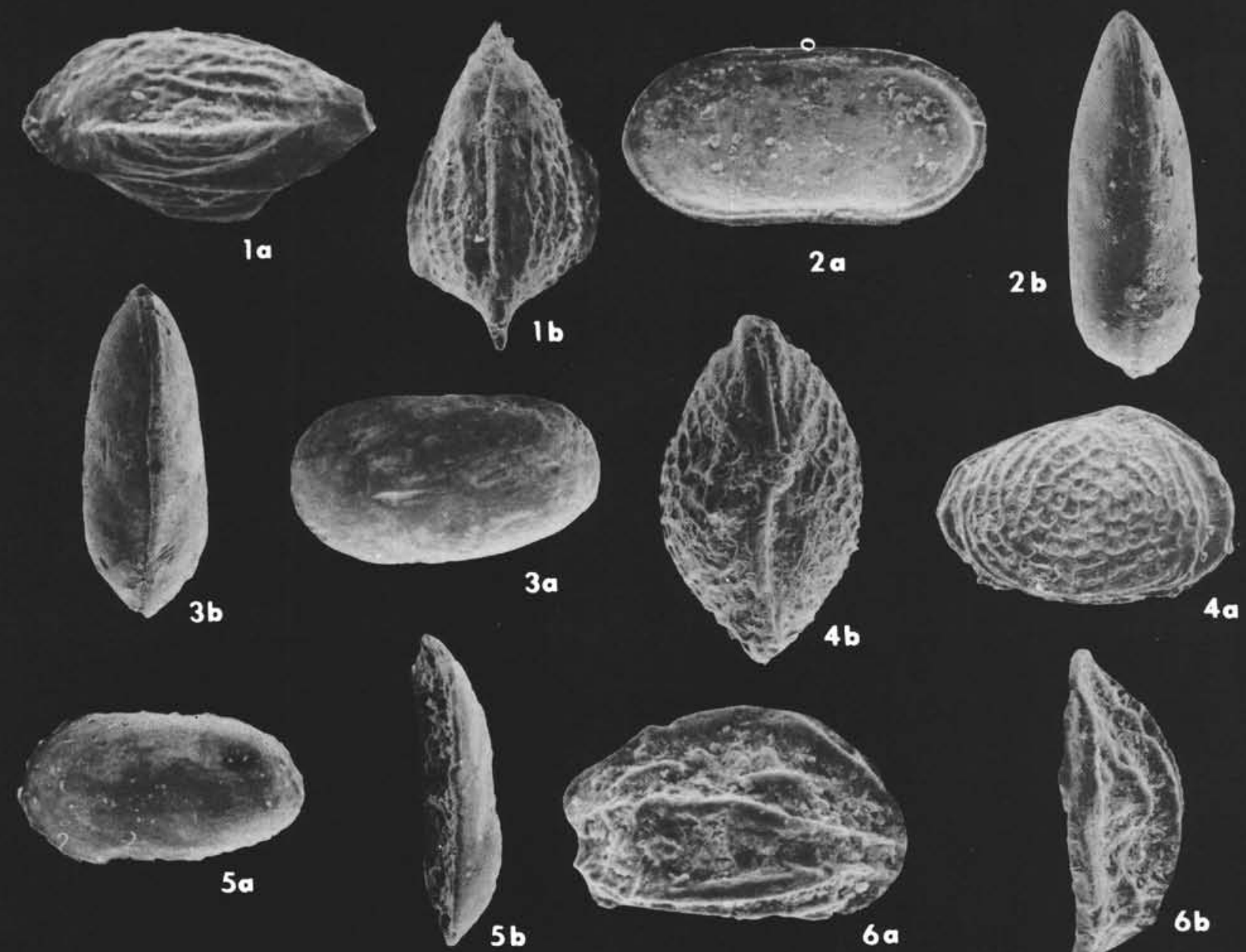

4a
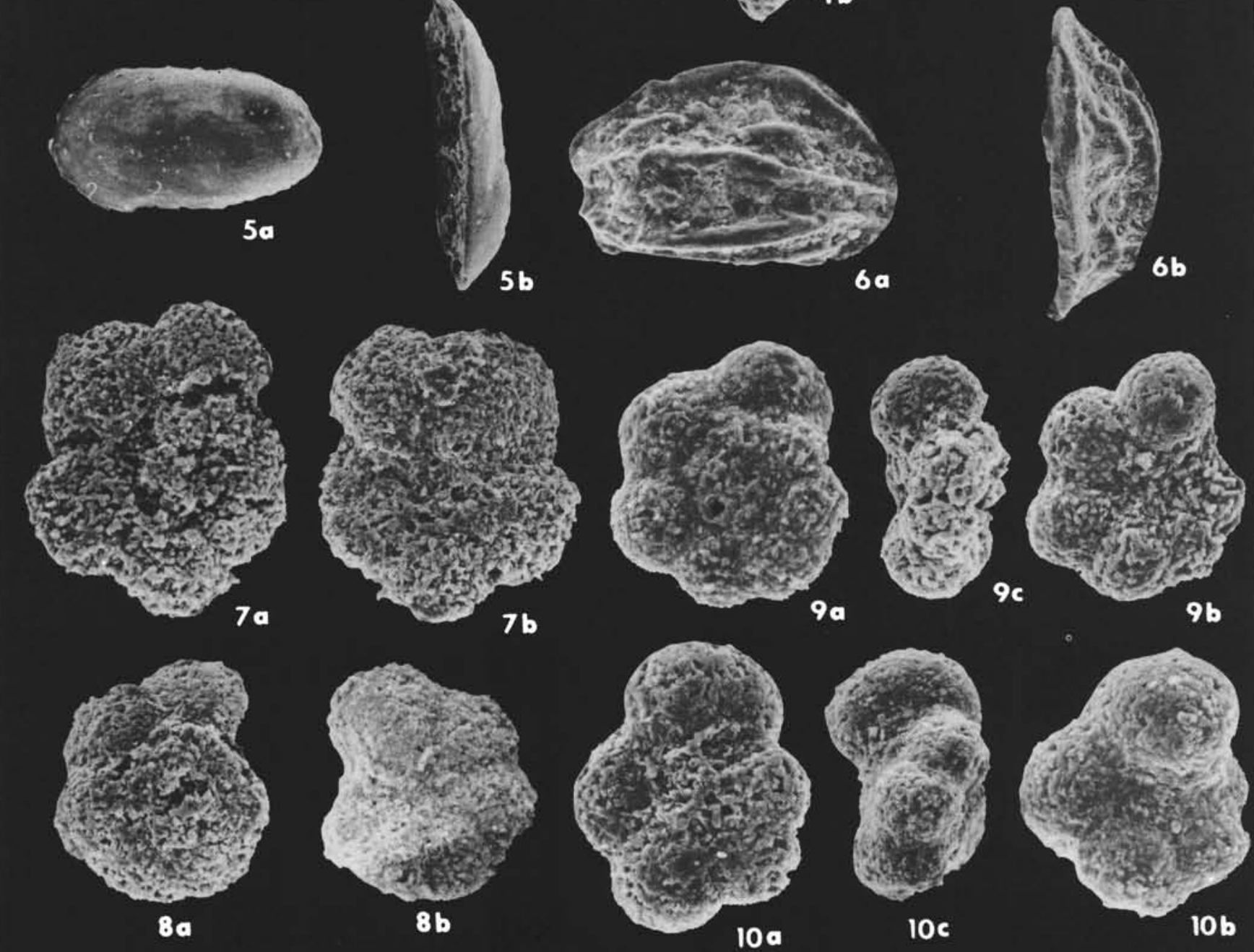


\section{PLATE 2}

Cretaceous

$(\mathrm{a}=$ spiral view $; \mathrm{b}=$ umbilical view; $\mathrm{c}=$ edge view. Stereoscan illustrations, Laboratoire de Géologie, Muséum National d'Histoire Naturelle, Paris)

Figure 1 Hedbergella cf. gauttierensis Brönnimann, 1952. Same exemplar. (a) $\times 170$ and (b) $\times 155$. Sample 249-23-3, $3 \mathrm{~cm}$; late Albian or early Cenomanian.

Figure 2 Globotruncana elevata (Brotzen, 1934). Same exemplar. (a) $\times 70$ and (b) $\times 80$. Sample 249-22-5, 40 $\mathrm{cm}$; late Campanian.

Figure 3 Globotruncana contusa (Cushman, 1926). Same exemplar. (a) $\times 70$ and (b) $\times 80$. Sample 249-21-3, $120 \mathrm{~cm}$; late Campanian.

Figure 4 Globotruncana calcarata Cushman, 1925. (a) $\times 70$ and (b) $\times 75$. Sample 249-21-3, $120 \mathrm{~cm}$; late Campanian.

Figure 5 Globotruncana adamsi el Naggar, 1966. Same exemplar. (a) $\times 110$ and (b) $\times 125$. Sample 249-19-3, $110 \mathrm{~cm}$; early Maestrichtian.

Figure $6 \quad$ Globotruncana citae Bolli, 1951. (a) $\times 105$, (b) $\times 110$ and (c) X125. Sample 249-17-2, $120 \mathrm{~cm}$; late Maestrichtian; same exemplar for (b) and (c).

Figure $7 \quad$ Globotruncana mayaorensis Bolli, 1951. (a) $\times 105$, (b) $\times 110$, and (c) $\times 105$. Sample 249-16, CC; late Maestrichtian.

Figure $8 \quad$ Globotruncana stuarti (J. de Lappar, 1918). (a) $\times 60$ and (b) $\times 70$. Sample 249-17-1, $78 \mathrm{~cm}$; late Maestrichtian. 
Plate 2
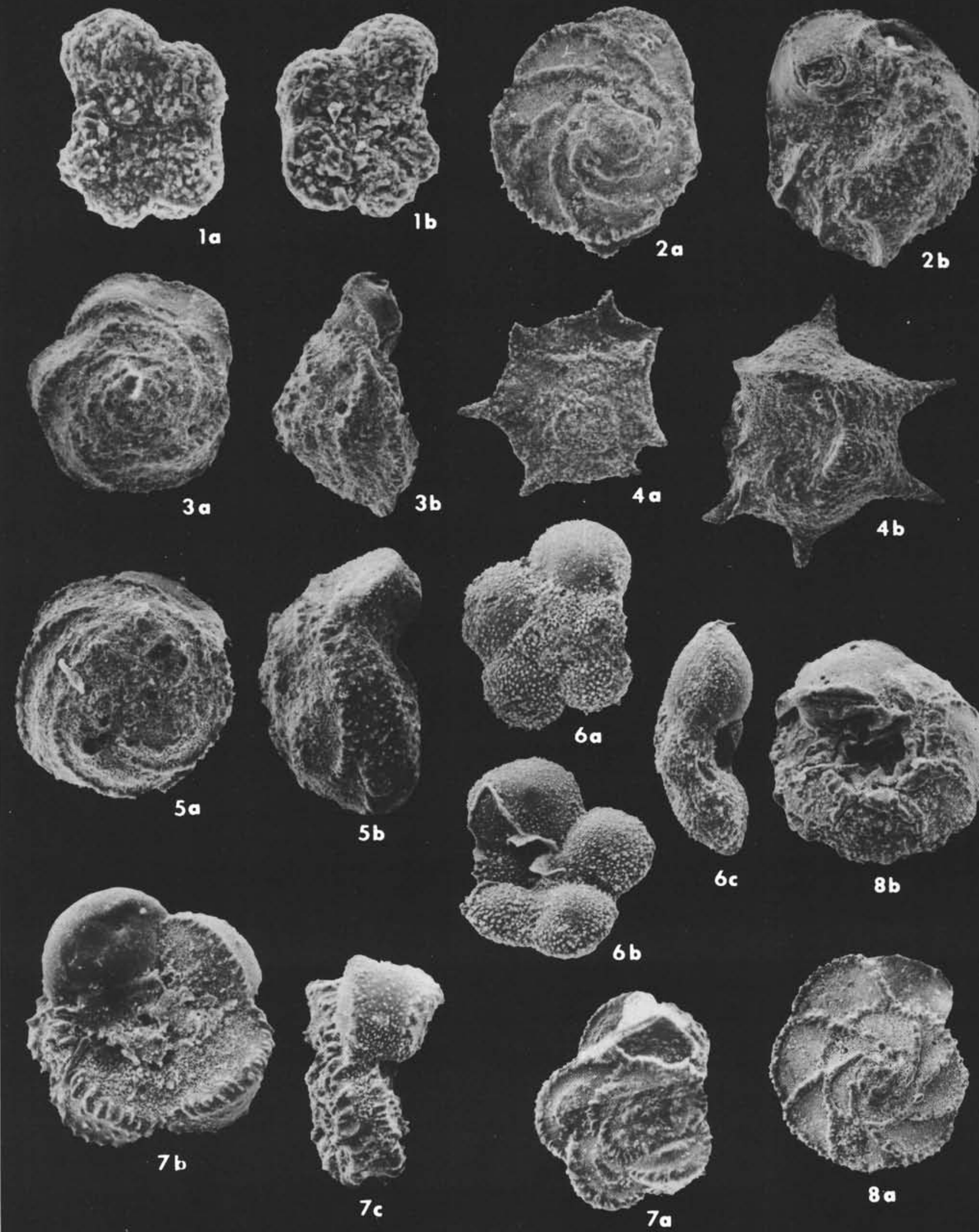


\section{PLATE 3}

Paleocene

$(\mathrm{a}=$ spiral view; $\mathrm{b}=$ umbilical view; $\mathrm{c}=$ edge view; except for Figure 2 where $\mathrm{b}$ corresponds to edge view. Stereoscan illustrations, Laboratoire de Géologie, Muséum National d'Histoire Naturelle, Paris)

Figure 1 Globoconusa daubjergensis (Brönnimann, 1952). (a) $\times 220$, (b) $\times 185$, and (c) $\times 185$. Sample 245-15-2, 100 $\mathrm{cm}$; Danian.

Figure 2 Globoconusa conusa Khalilov, 1956. (a) $\times 200$ and (b) X185. Sample 245-15-3, $125 \mathrm{~cm}$; Danian.

Figure 3 Globigerina (Subbotina) triloculinoides Plummer, 1926. (a) and (c) $\times 125$ and (b) $\times 130$. Sample 245-13-6, $50 \mathrm{~cm}$; Danian.

Figure 4 Globigerina (Subbotina) trivialis Subbotina, 1953. (a) $\times 125$, (b) and (c) $\times 130$. Sample 245-16, CC; Danian.

Figure 5 Globorotalia (Turborotalia) pseudobulloides (Plummer, 1926). (a) $\times 140$, (b) and (c) $\times 135$. Sample 245-16, CC; Danian.

Figure 6 Globorotalia (Turborotalia) compressa (Plummer, 1926). (a) $\times 125$, (b) $\times 145$ and (c) $\times 135$. Sample 245-16, CC; Danian.

Figure 7 Globorotalia (Turborotalia) cf. quadrata (White, 1928). (a) $\times 135$, (b) and (c) $\times 130$. Sample 245-16, CC; Danian. 
PLATE 3

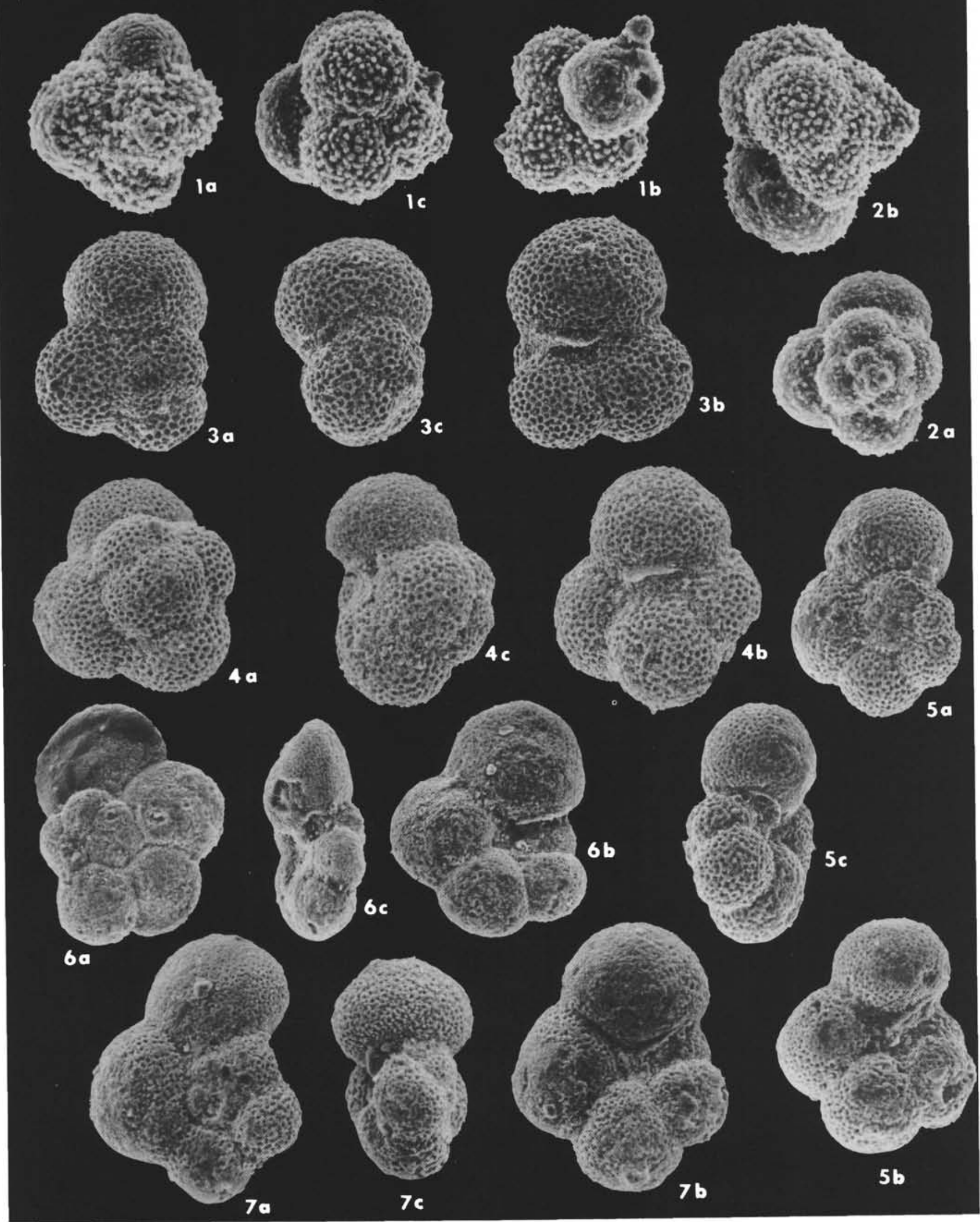




\section{PLATE 4}

Paleocene, Early Eocene

$(\mathrm{a}=$ spiral view; $\mathrm{b}=$ umbilical view; $\mathrm{c}=$ edge view; except for Figure 2 where b. corresponds to edge view. Stereoscan illustrations, Laboratoire de Géologie, Muséum National d'Histoire Naturelle, Paris)

Figure 1 Globorotalia (Morozovella) angulata (White, 1928). (a) $\times 165$, (b) $\times 185$, and (c) $\times 170$. Sample 245-14-1, $100 \mathrm{~cm}$; early Paleocene.

Figure 2 Globorotalia (Turborotalia) trinidadensis Bolli, 1957. (a) $\times 155$ and (b) $\times 150$. Sample $245-14-3,115 \mathrm{~cm}$; early Paleocene.

Figure 3 Globorotalia (Morozovella) conicotruncata (Subbotina, 1953). (a) $\times 110$, (b) and (c) $\times 130$. Sample 245-13-6, $50 \mathrm{~cm}$; early Paleocene.

Figure 4

Globorotalia (Morozovella) velascoensis (Cushman, 1925). (a) $\times 90$, (b) and (c) $\times 100$. Sample 245-9-3, $100 \mathrm{~cm}$; late Paleocene.

Figure 5 Globorotalia (Turborotalia) ehrenbergi Bolli, 1957. (a) $\times 165$, (b) $\times 160$, and (c) $\times 180$. Samples 245-13-6, $50 \mathrm{~cm}$ (for a and b), 245-13-6, $100 \mathrm{~cm}$ (for c); late Paleocene.

Figure 6

Globorotalia (Turborotalia) pseudoscitula group Glaessner,, 1937. (a) and (c) $\times 170$, and (b) $\times 195$. Sample 245-8-1, $145 \mathrm{~cm}$; earliest Eocene. 
PLATE 4
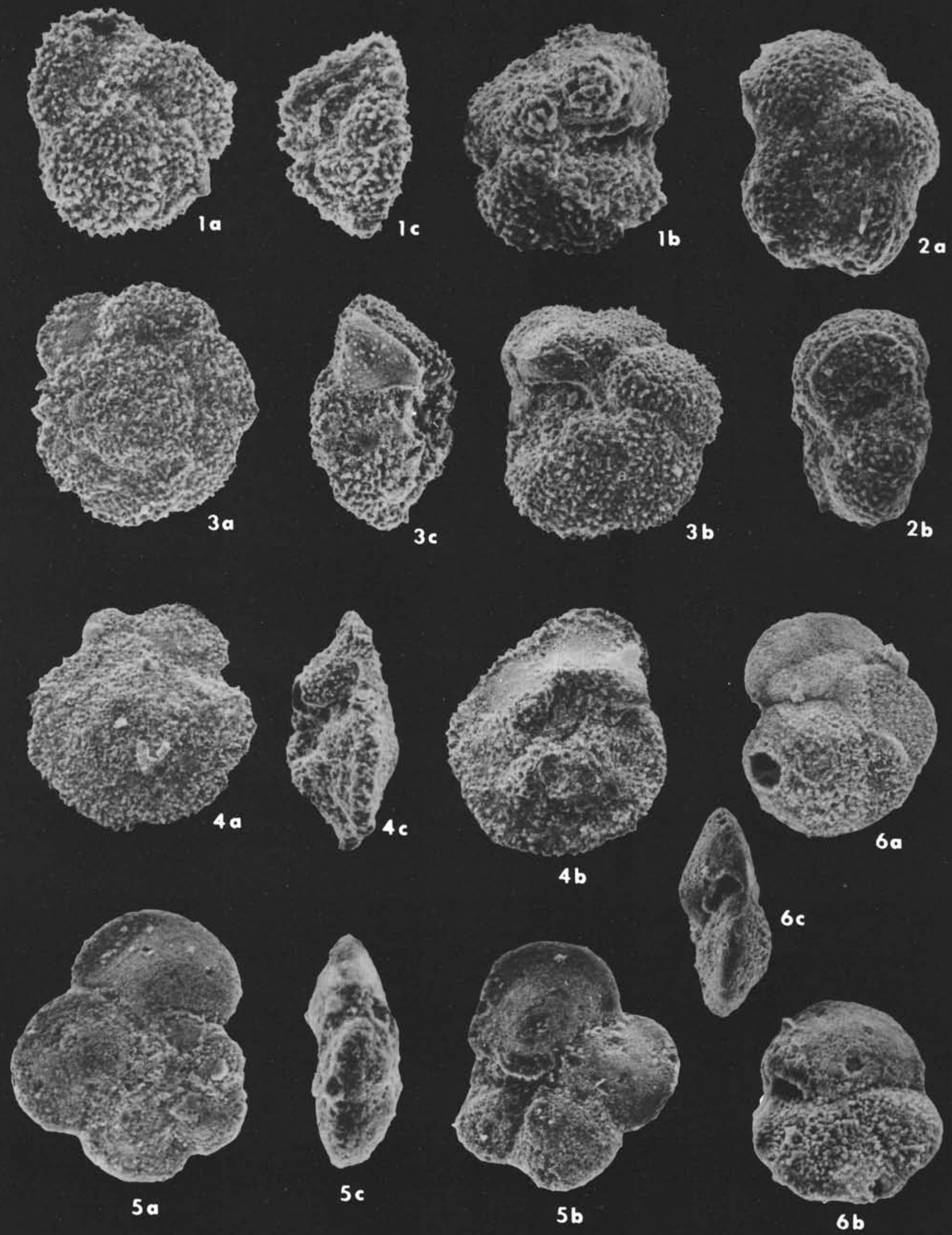


\section{PLATE 5}

Paleocene, Early Eocene

( $\mathrm{a}=$ spiral view $; \mathrm{b}=$ umbilical view; $\mathrm{c}=$ edge view. Stereoscan illustrations, Laboratoire de Géologie, Muséum National d'Histoire Nautrelle, Paris)

Figure 1 Globorotalia (Acarinina) mckannai (White, 1928). (a), (b), and (c) $\times 150$. Samples $245-9-3,100 \mathrm{~cm}$ (for $\mathrm{a}$ and c), 245-8-1, $145 \mathrm{~cm}$ (for b); late Paleocene and earliest Eocene, respectively.

Figure 2 Globorotalia (Acarinina) acquiensis (Loeblich and Tappan, 1957). Lateral view, X150. Sample 245-9-3, $100 \mathrm{~cm}$; late Paleocene.

Figure 3 Globorotalia (Acarinina) whitei Weiss, 1928. (a), (b), and (c) $\times 135$. Sample 245-9-3, $100 \mathrm{~cm}$; late Paleocene.

Figure 4 Globorotalia (Morozovella) occlusa Loeblich et Tappan, 1957. (a) $\times 110$, (b) $\times 105$, and (c) $\times 115$. Sample 245-9-3, $100 \mathrm{~cm}$; late Paleocene.

Figure 5 Globorotalia (Planorotalites) pseudomenardii Bolli, 1957. (a) $\times 155$, (b) $\times 180$, and (c) $\times 150$. Sample 245-9-3, $100 \mathrm{~cm}$; late Paleocene.

Figure 6 Globigerina (Subbotina) cf. incisa Hillebrandt, 1962. (a) $\times 130$, (b) and (c) $\times 115$. Sample 245-10-1, $30 \mathrm{~cm}$; late Paleocene.

Figure $7 \quad$ Globorotalia (Turborotalia) cf. perclara Loeblich and Tappan, 1957. (a) $\times 230$, (b) $\times 220$, and (c) $\times 205$. Sample 245-8-1, $145 \mathrm{~cm}$; earliest Eocene. 
PLATE 5
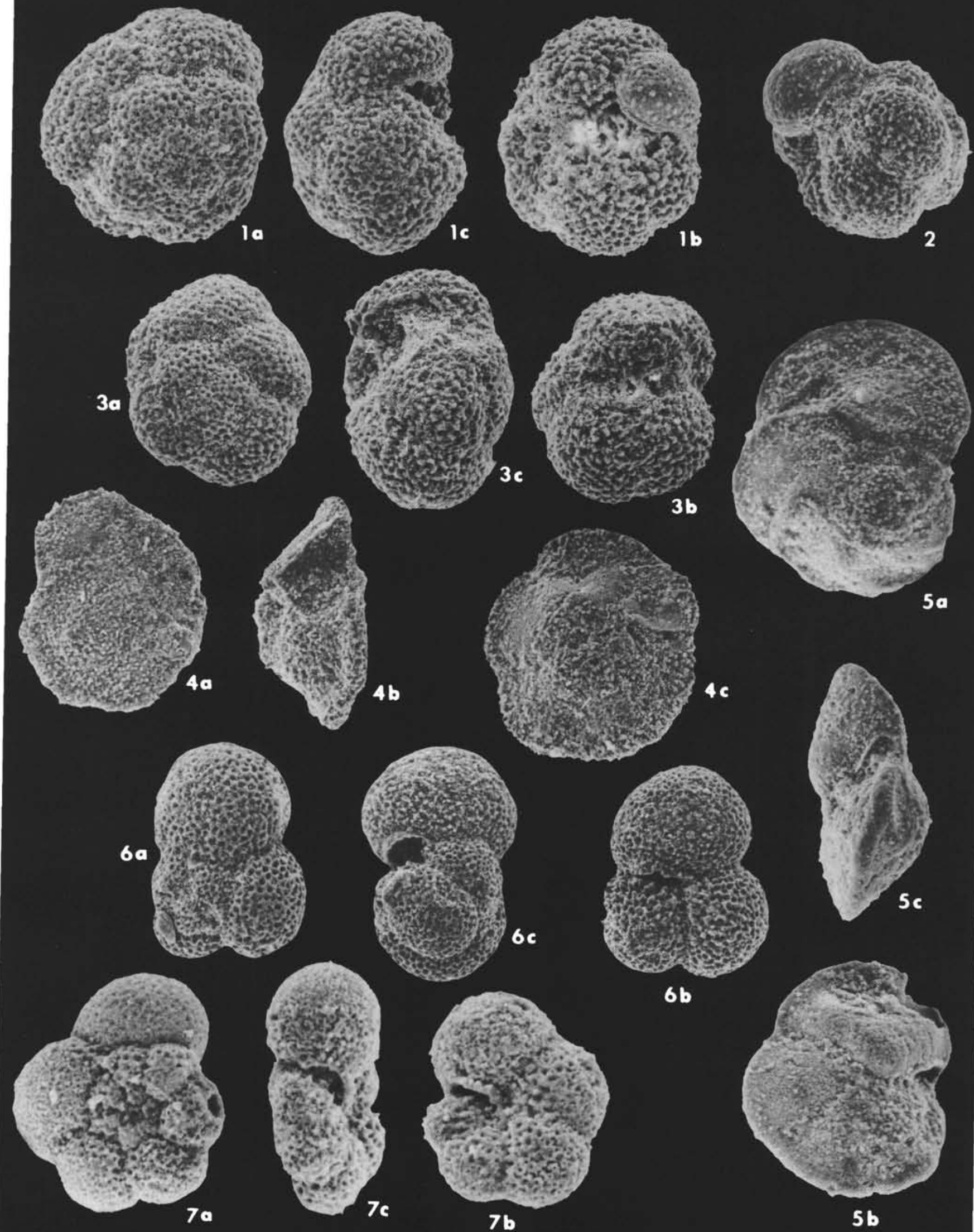

$6 c$
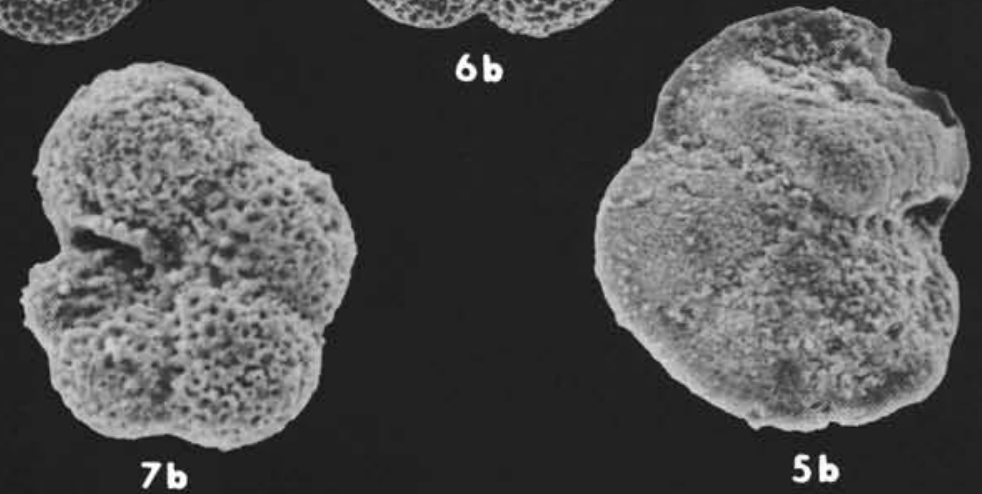


\section{PLATE 6}

Late Paleocene, Early Eocene

$(\mathrm{a}=$ spiral view; $\mathrm{b}=$ umbilical view; $\mathrm{c}=$ edge view; except for Figure 5 . Stereoscan illustrations, Laboratoire de Géologie, Muséum National d'Histoire Naturelle, Paris)

Figure 1 Globorotalia (Acarinina) soldadoensis (Brönnimann, 1952). (a), (b), and (c) $\times 110$. Sample $245-5-2,58 \mathrm{~cm}$; early Eocene; same exemplar for (a) and (c).

Figure 2 Globigerina (?Globoconusa) chascanona Loeblich and Tappan, 1957. (a) $\times 225$, (b) $\times 220$, and (c) $\times 215$. Sample 245-8-1, $145 \mathrm{~cm}$; earliest Eocene.

Figure 3 Globorotalia (Morozovella) aequa Cushman and Renz, 1942. (a) $\times 100$, (b) and (c) $\times 95$. Sample 245-8-1, $145 \mathrm{~cm}$; earliest Eocene.

Figure 4 Globorotalia (Morozovella) subbotinae Morozova, 1939. (a) $\times 95$, (b) $\times 80$, and (c) $\times 100$. Sample 245-8-1, $145 \mathrm{~cm}$; earliest Eocene.

Figure 5 Pseudohastigerina wilcoxensis (Cushman and Ponton, 1932). (a) lateral view and (b) edge view; $X 180$. Sample 246-5-4, $120 \mathrm{~cm}$; early Eocene.

Figure 6

Globorotalia (Acarinina) angulosa (Bolli, 1957). (a) and b) $\times 110$ and (b) $\times 115$. Sample $245 \mathrm{~A}-7-4,110$ $\mathrm{cm}$; early Eocene.

Figure 7 Globigerina (Globigerina) velascoensis Cushman, 1925. (a) $\times 120$, (b) and (c) $\times 115$. Samples 245-9-3, $100 \mathrm{~cm}$ (for a and c), 245-8-1, $145 \mathrm{~cm}$ (for b); late Paleocene and earliest Eocene, respectively. 
PLATE 6
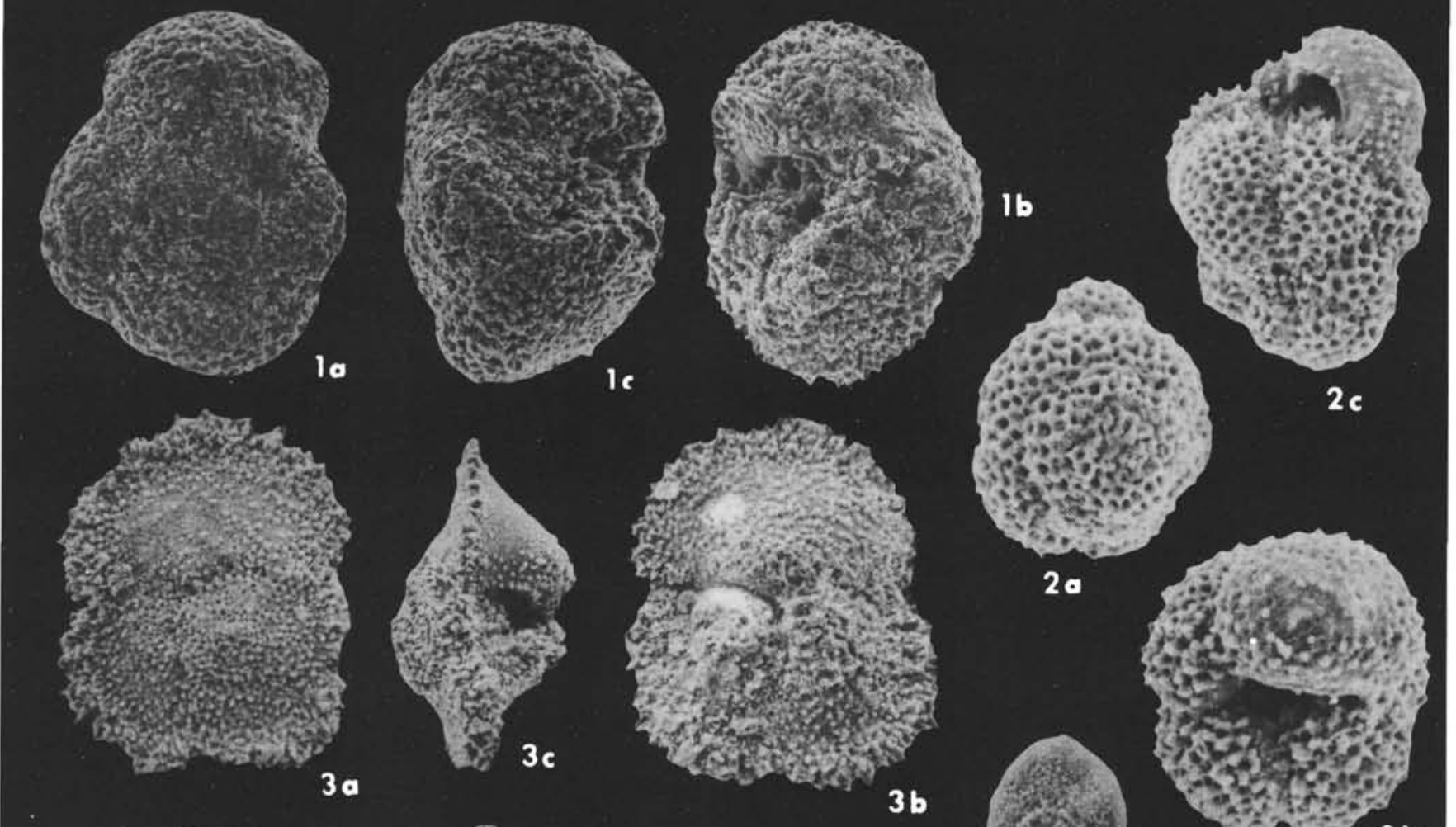

Q 350.250.

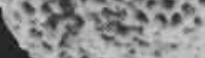
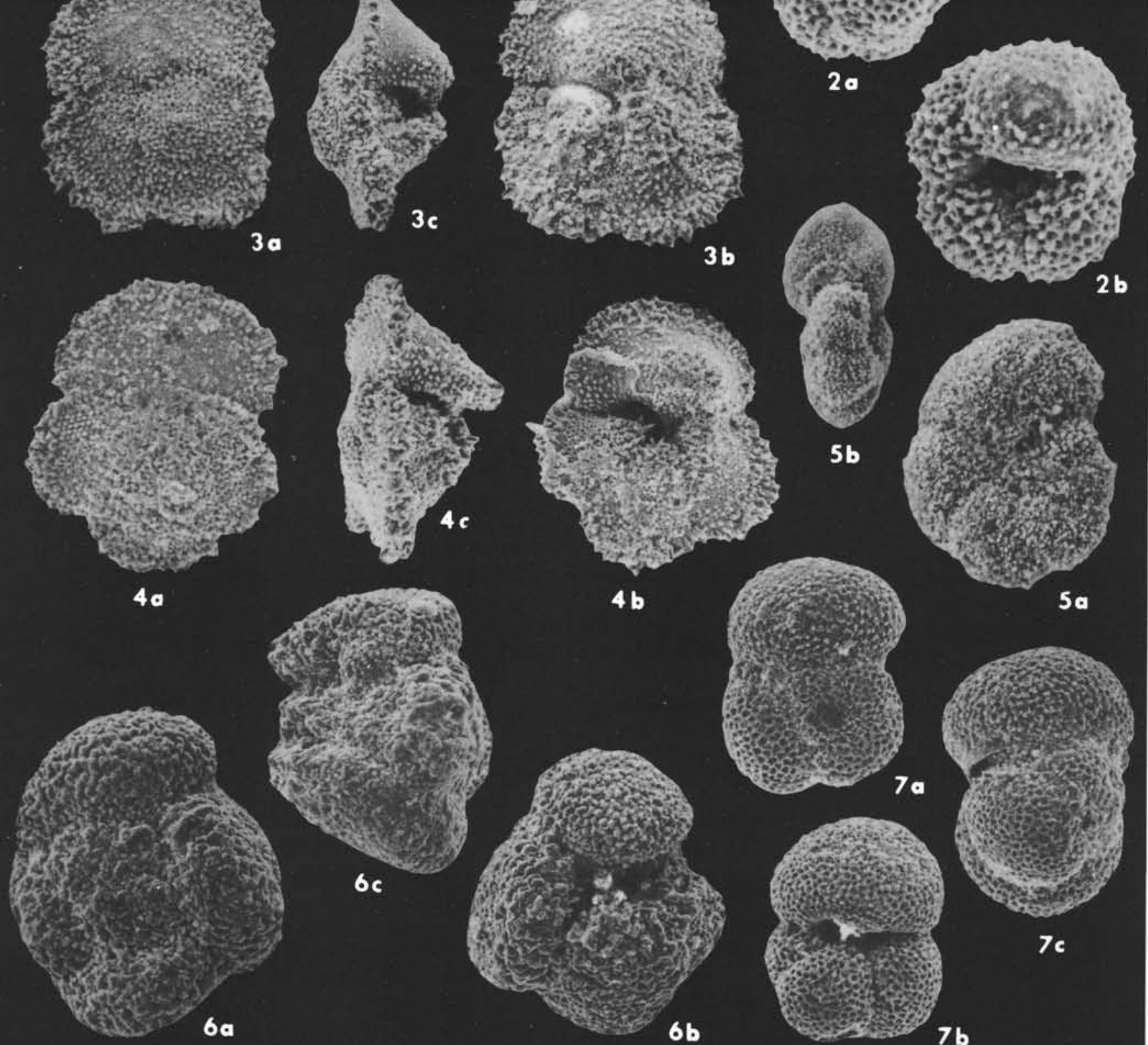

26

$4 b$
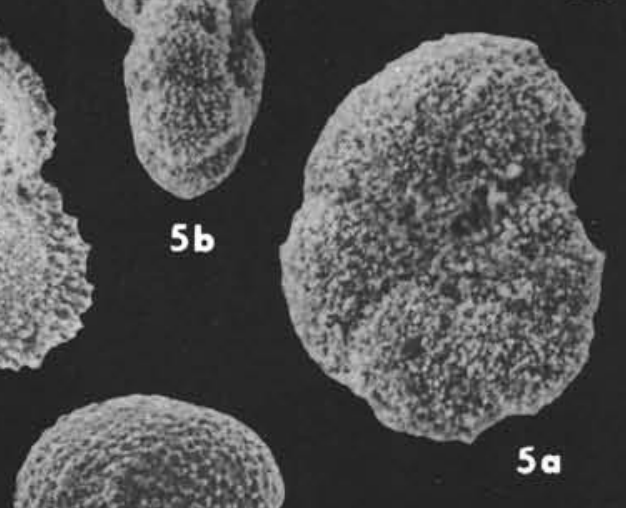

$5 a$

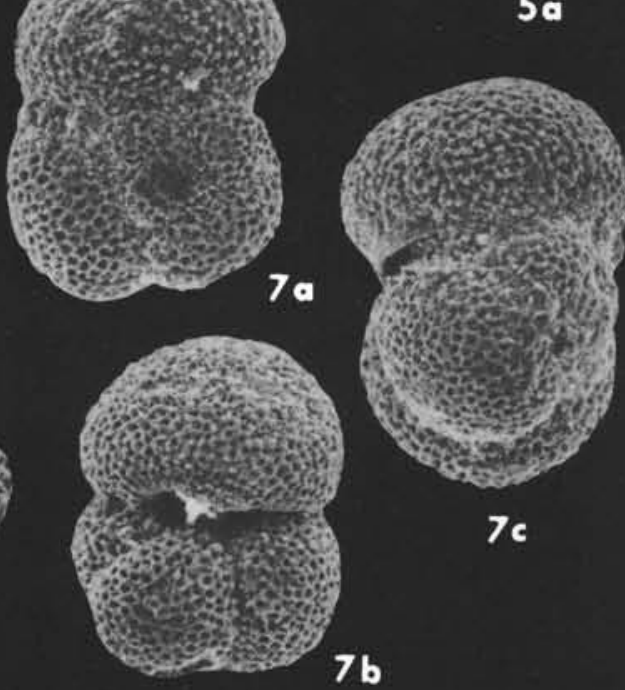




\section{PLATE 7}

Late Paleocene, Early Eocene

$(\mathrm{a}=$ spiral view; $\mathrm{b}=$ umbilical view; $\mathrm{c}=$ edge view. Stereoscan illustrations, Laboratoire de Géologie, Muséum National d'Histoire Naturelle, Paris)

Figure $1 \quad$ Globorotalia (Acarinina) convexa Subbotina, 1953. (a) and (c) $\times 225$, and (b) $\times 180$. Sample 245-10-1, 30 $\mathrm{cm}$; late Paleocene.

Figure 2 Globorotalia (Acarinina) pseudotopilensis Subbotina, 1953. (a) $\times 135$, (b) $\times 130$, and (c) $\times 125$. Sample 245-8-1, $145 \mathrm{~cm}$; earliest Eocene; same exemplar for (b) and (c).

Figure 3 Globorotalia (Acarinina) esnaensis (Le Roy, 1953). (a) and (b) $\times 135$, (c) $\times 120$. Sample 245-8-1, $145 \mathrm{~cm}$; earliest Eocene; same exemplar for (a) and (c).

Figure 4 Globorotalia (Acarinina) triplex Subbotina, 1953. (a) $\times 110$, (b) $\times 130$, and (c) $\times 120$. Sample $245-7-1,100$ $\mathrm{cm}$; early Eocene.

Figure 5 Globorotalia (Morozovella) dolabrata Jenkins, 1965. (a) $\times 95$, (b) $\times 110$, and (c) $\times 100$. Sample 245-8-1, $145 \mathrm{~cm}$; earliest Eocene.

Figure 6 Globorotalia (Acarinina) acarinata Subbotina, 1953. (a) and (c) $\times 135$, and (b) $\times 150$. Sample 245-6-1, 110 $\mathrm{cm}$; early Eocene.

Figure $7 \quad$ Globorotalia (Morozovella) wilcoxensis Cushman and Ponton, 1932. (a) and (c) $\times 135$, and (b) $\times 140$. Sample 245-8-1, $145 \mathrm{~cm}$; earliest Eocene. 
PLATE 7
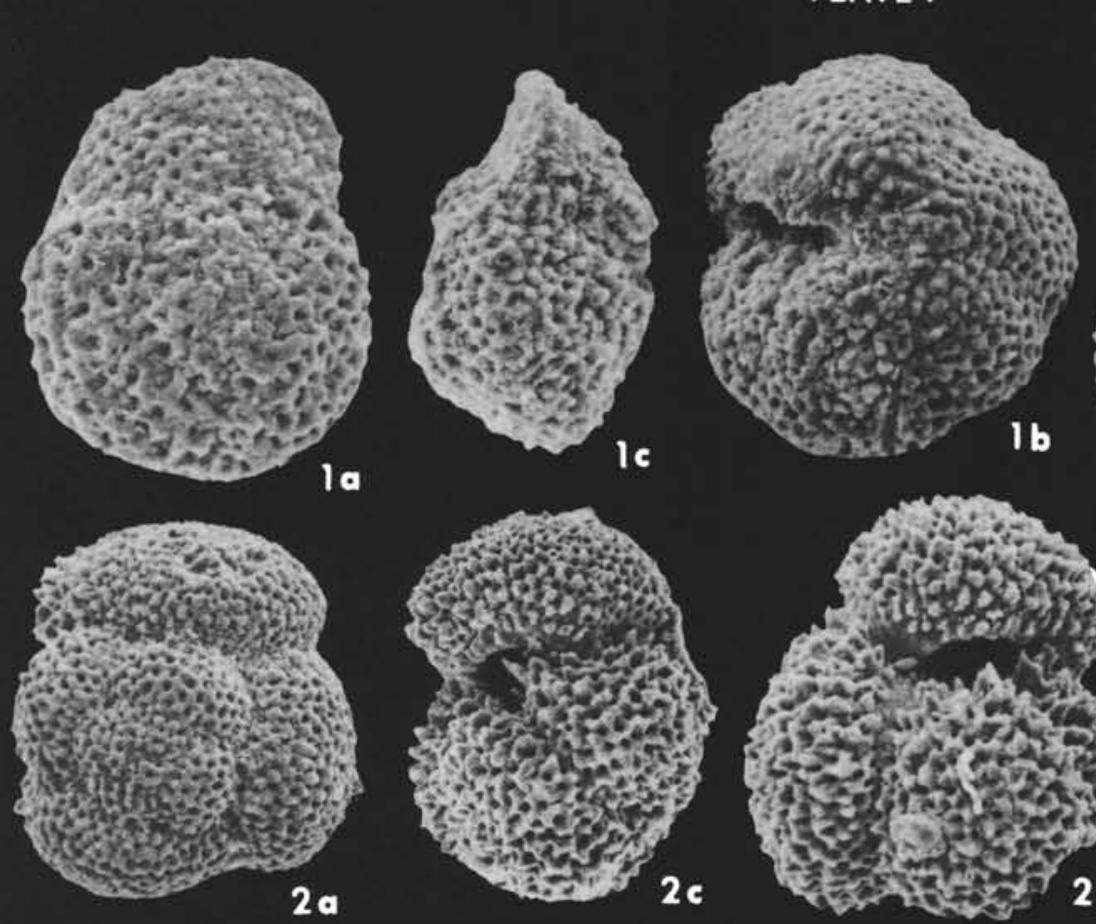

conosist solos 3. Yis

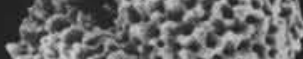
siseroungs: \& $\rightarrow$ rotas?
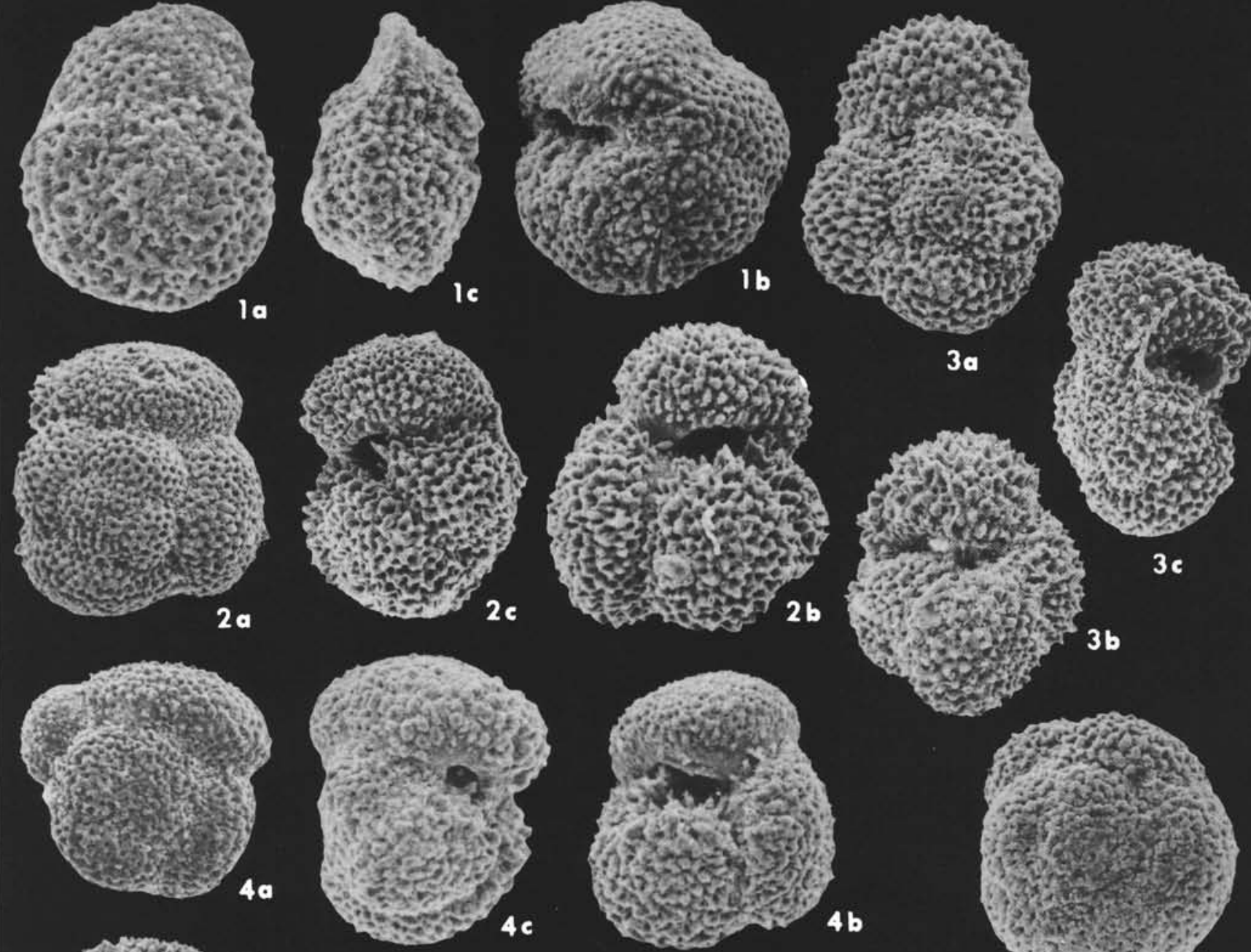

3b
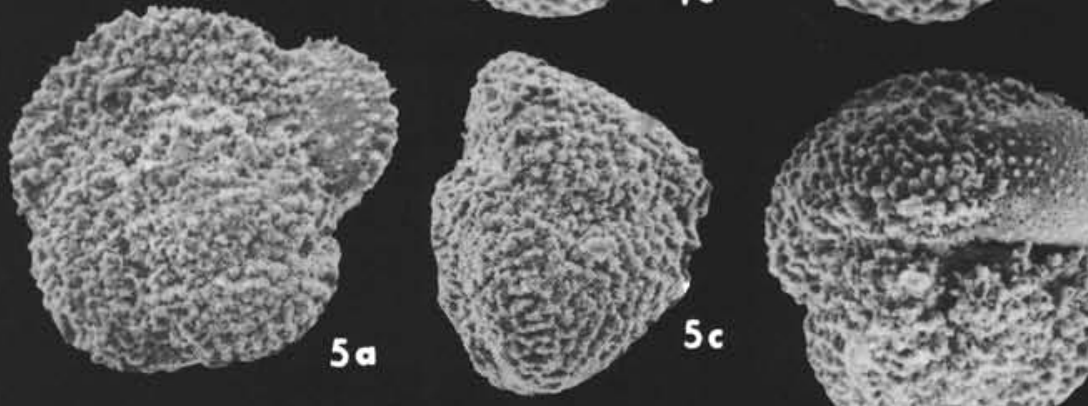

$4 b$

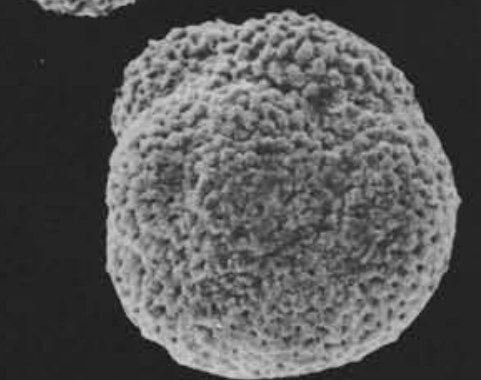

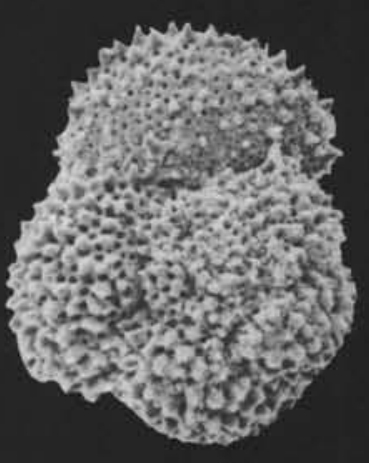

$7 \mathbf{a}$
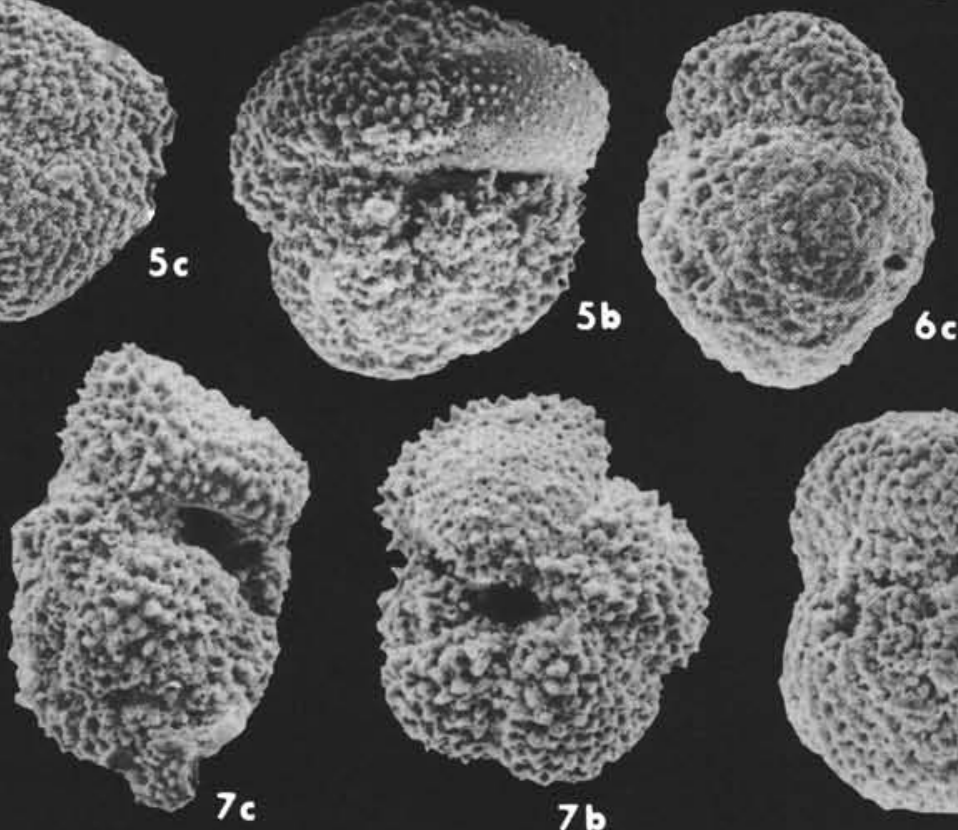

$6 \mathbf{a}$
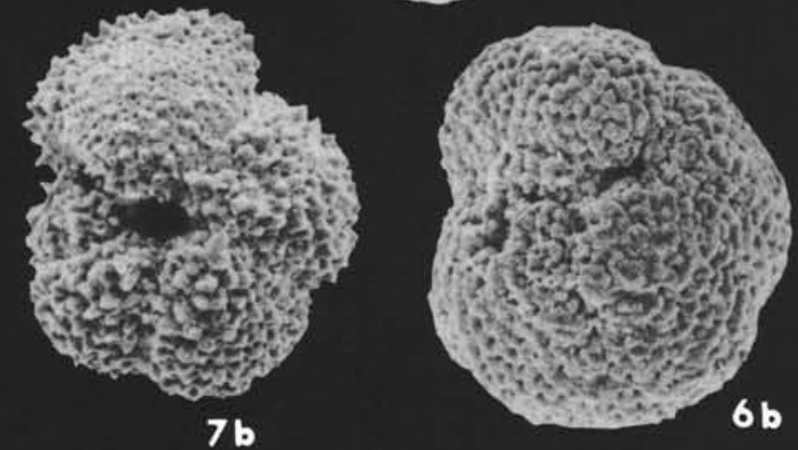
PLATE 8

Early Eocene

$(\mathrm{a}=$ spiral view; $\mathrm{b}=$ umbilical view; $\mathrm{c}=$ edge view. Stereoscan illustrations, Laboratoire de Géologie, Muséum National d'Histoire Naturelle, Paris)

Figure 1 Globorotalia (Acarinina) spinuloinflata (Bandy, 1949). (a), (b), and (c) X110. Sample 245A-7-6, 130 $\mathrm{cm}$; late early Eocene.

Figure 2 Globorotalia (Turborotalia) salisburgensis Gohrbandt, 1967. (a) and (b) $\times 125$, and (c) $\times 130$. Sample 245-8-1, 145 cm; earliest Eocene.

Figure 3 Globorotalia (Turborotalia) traubi Gohrbandt, 1967. (a) $\times 155$, (b) $\times 165$, and (c) $\times 145$. Sample 245-8-1, $145 \mathrm{~cm}$; earliest Eocene; same exemplar for (a) and (c).

Figure 4 Globorotalia (Morozovella) aragonensis Nuttal, 1930. (a) and (b) $\times 100$, and (c) $\times 95$. Sample 245-5-2, 58 $\mathrm{cm}$; early Eocene.

Figure $5 \quad$ Globorotalia (Morozovella) crater Finlay, 1939. (a) $\times 100$, (b) and (c) $\times 70$. Sample $245-5-4,57 \mathrm{~cm}$; early Eocene.

Figure $6 \quad$ Globorotalia (Morozovella) gr. bullbrocki Bolli, 1957. (a) and (c) $\times 115$, and (b) $\times 135$. Sample 245-5-2, 58 cm; early Eocene. 
PLATE 8
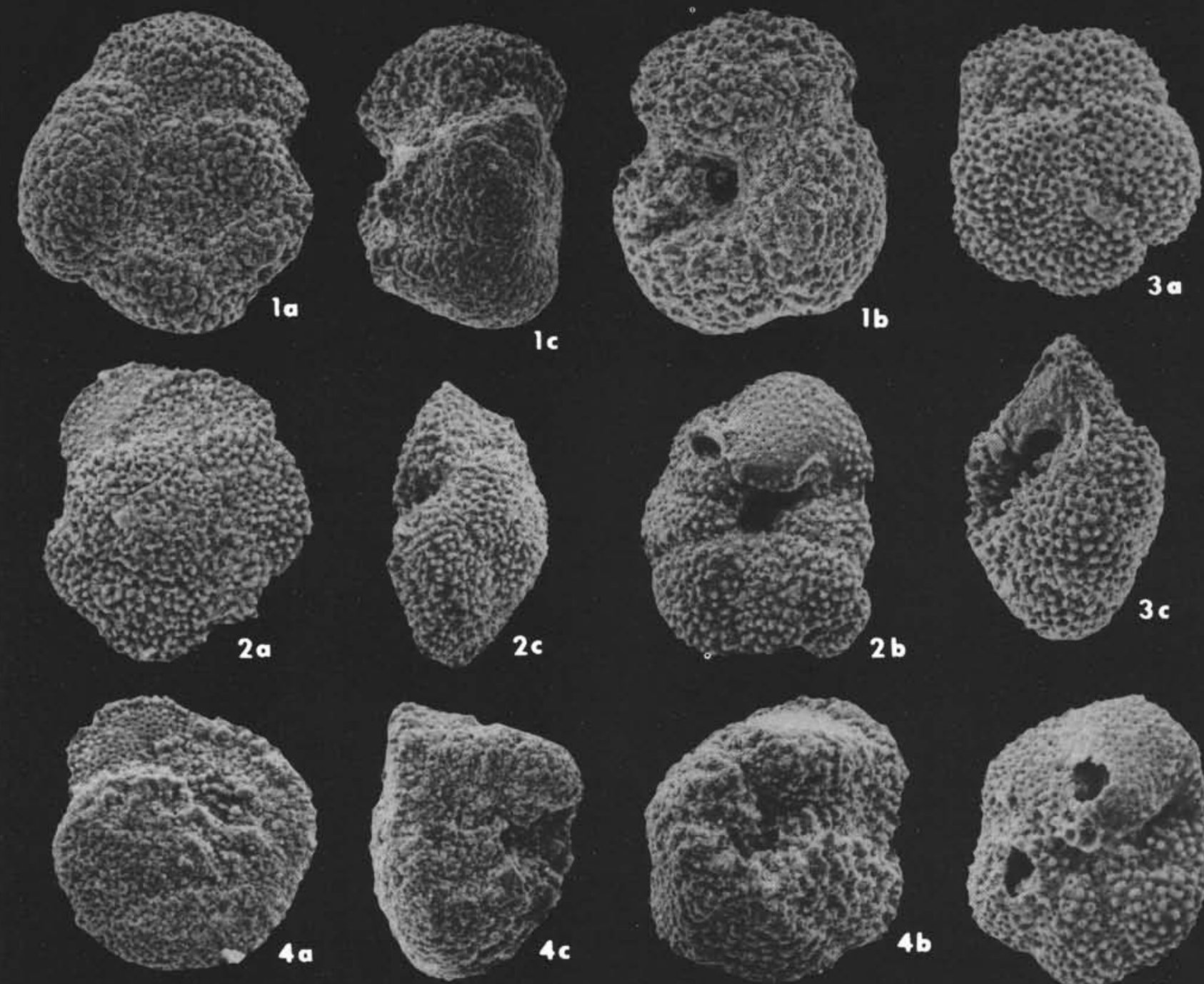

26
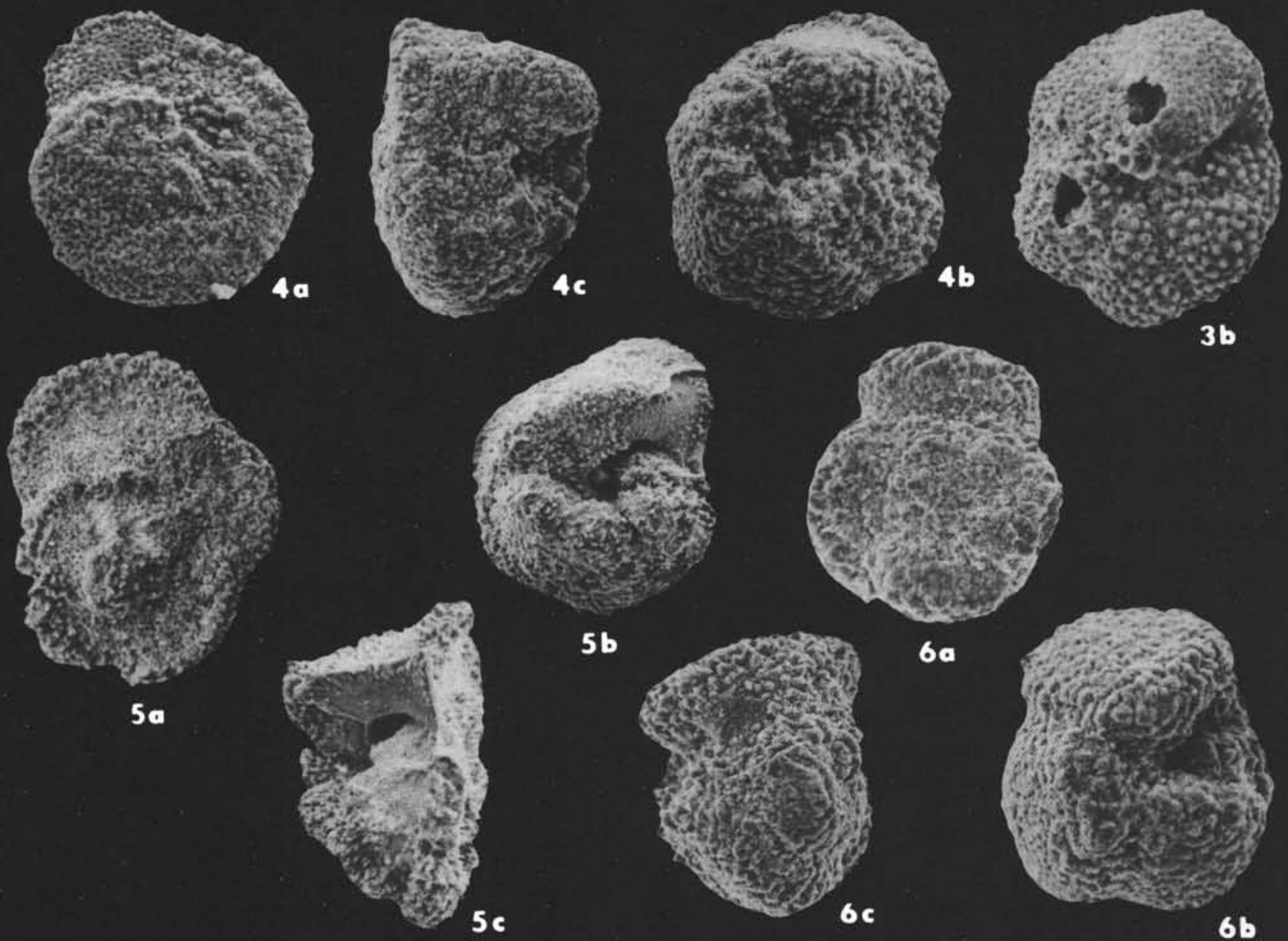

c

$5 b$

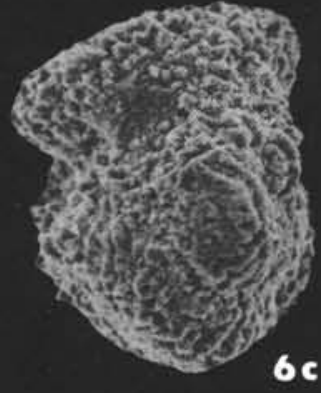

$6 a$

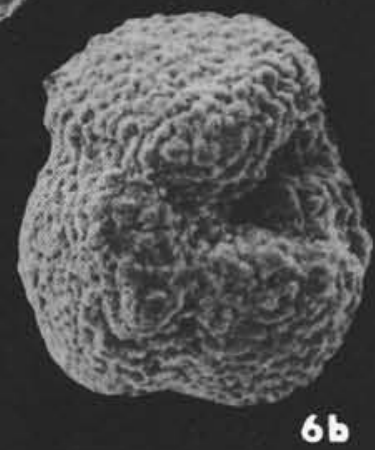




\section{PLATE 9}

Early to Late Eocene

$(\mathrm{a}=$ spiral view; $\mathrm{b}=$ umbilical view; $\mathrm{c}=$ edge view; except for Figures 2 and 3. Stereoscan illustrations, Laboratoire de Géologie, Muséum National d'Histoire Naturelle, Paris)

Figure 1

Globigerina (Globigerina) cf. boweri Bolli, 1957. (a) $\mathrm{X} 135$,. (b) and (c) $\times 130$. Samples 245-3-6, $75 \mathrm{~cm}$ (for a and b), 245-5-2, $58 \mathrm{~cm}$ (for c); middle Eocene and early Eocene, respectively.

Figure 2 Globigerina sp., ?cf. Globigerinoides higginsi Bolli, 1957. Edge view, $X 200$. Sample $245-5-4,52 \mathrm{~cm}$; early Eocene.

Figure 3 Globigerina cf. jacksonensis Bandy, 1949. Spiral view, X60. Sample $242-19-2,100 \mathrm{~cm}$; early late Eocene.

Figure 4 Globigerina cf. jacksonensis Bandy, 1949. (a) X65, (b) and (c) X75. Samples 242-19, CC (for a and c), 242-19-2, $100 \mathrm{~cm}$ (for b); early late Eocene.

Figure 5 ?Globigerina senni (Beckmann, 1954). (a), (b) and (c) X120. Sample 245-5-3, $110 \mathrm{~cm}$; early Eocene.

Figure 6 Globigerina gr. eocaena Gümbel, 1870. (a), (b) and (c) $\times 75$. Samples 242-19-2, $100 \mathrm{~cm}$ (for a), 242-19, $\mathrm{CC}$ (for b and c); early late Eocene.

Figure $7 \quad$ Globigerina corpulenta Subbotina, 1953. (a), (b) and (c) $\times 60$. Sample 242-19-2, $100 \mathrm{~cm}$; early late Eocene.

Figure $8 \quad$ Globigerina praeturritilina Blow and Banner, 1962. (a) and (c) $\times 90$, (b) $\times 65$. Sample 242-19-2, $100 \mathrm{~cm}$; early late Eocene; same exemplar for (a) and (c). 


\section{PLATE 9}
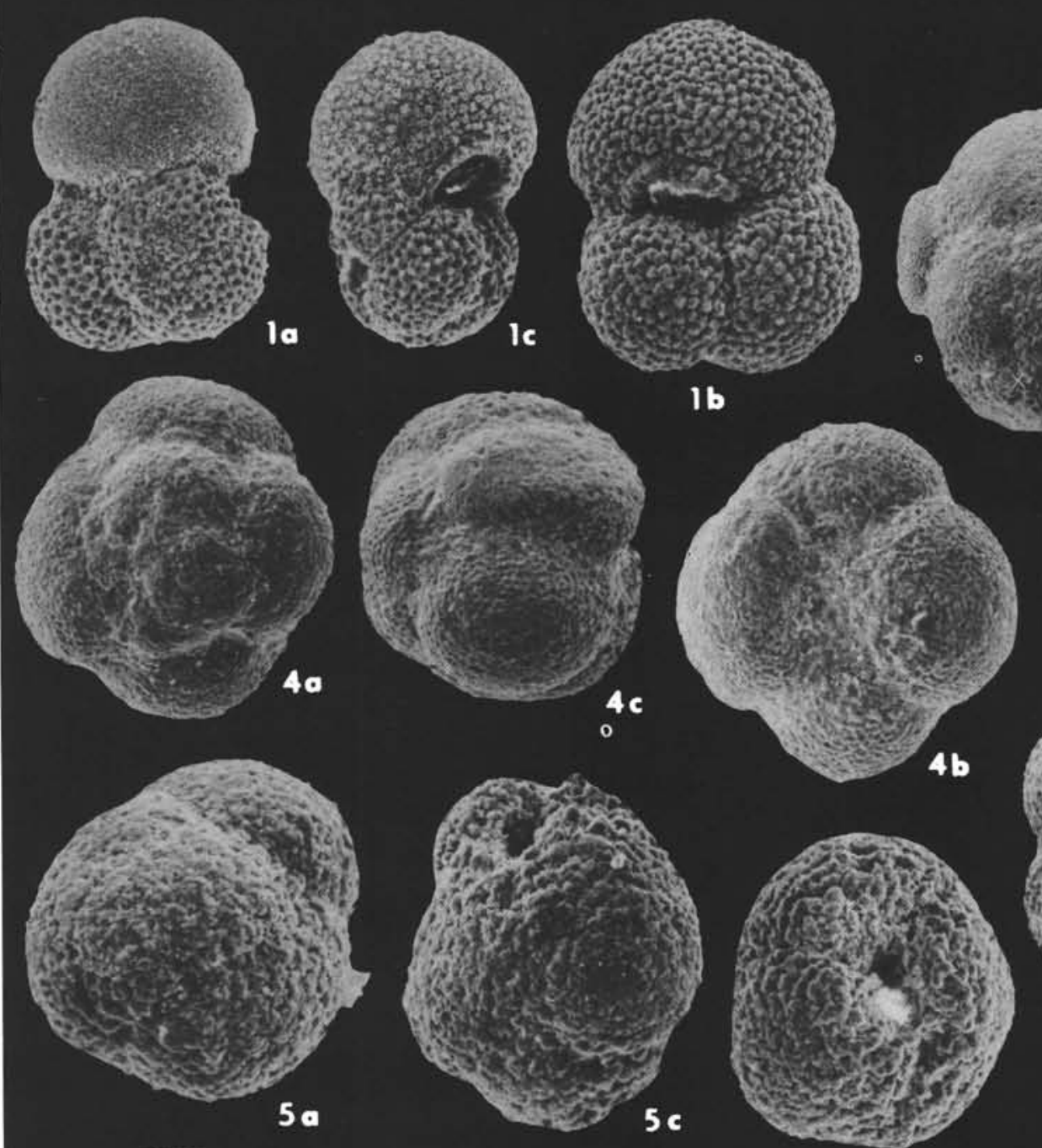

3

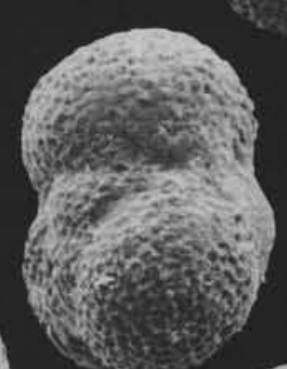

$6 a$

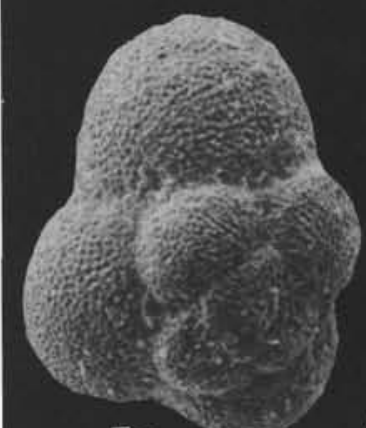

$7 a$

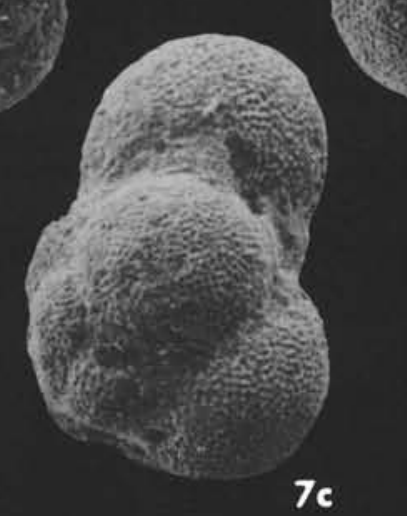

$7 b$

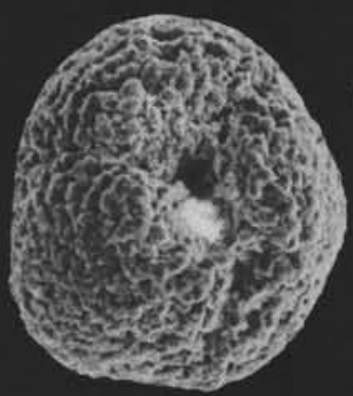

$6 c$

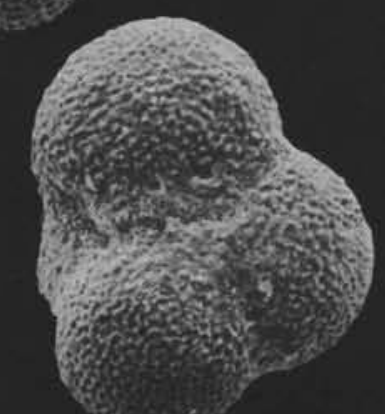

$6 b$ 
PLATE 10

Early Late Eocene

( $\mathrm{a}=$ spiral view, $\mathrm{b}=$ umbilical view, $\mathrm{c}=$ edge view; except for Figures 5 and 6. Stereoscan illustrations, Laboratoire de Géologie, Muséum National d'Histoire Naturelle, Paris)

Figure 1 Globigerina (Subbotina) angiporoides Hornibrook, 1965. (a) $\times 150$ and (b) $\times 165$. Samples $242-19$, CC (for a), 242-19-2, $100 \mathrm{~cm}$ (for b); early late Eocene.

Figure 2 Globigerinita cf. africana Blow and Banner, 1962. (a) and (b) $\times 155$. Samples 242-18, CC (for a), 242-19-2, $100 \mathrm{~cm}$ (for b); early late Eocene.

Figure 3 Globigerinita globiformis Blow and Banner, 1962. (a) $\times 135$ and (b) $\times 125$. Sample 242-18, CC; early late Eocene.

Figure $4 \quad$ Globigerinita pera (Todd, 1957). (a) $\times 80$ and (b) X75. Sample 242-19-3, $100 \mathrm{~cm}$; early late Eocene.

Figure $5 \quad$ Globigerinatheka lindiensis Blow and Banner, 1962. (a) $\times 155$ and (b) $\times 160$. Samples 242-19-3, $100 \mathrm{~cm}$ (for a), 242-19-2, $100 \mathrm{~cm}$ for (b); early late Eocene.

Figure 6 Globigerinatheka semi-involuta (Keijzer, 1945). (a) $\times 185$, (b) $\times 155$, and (c) $\times 210$. Samples 242-19-2, 50 $\mathrm{cm}$ (for a and b), 242-19-3, $100 \mathrm{~cm}$ (for c); early late Eocene.

Figure $7 \quad$ Globorotalia $\mathrm{cf}$. truncorotaloides topilensis (Cushman, 1925). (a) $\times 115$, (b) $\times 130$, and (c) $\times 145$. Sample $242-19-3,100 \mathrm{~cm}$; early late Eocene; same exemplar. 
PLATE 10
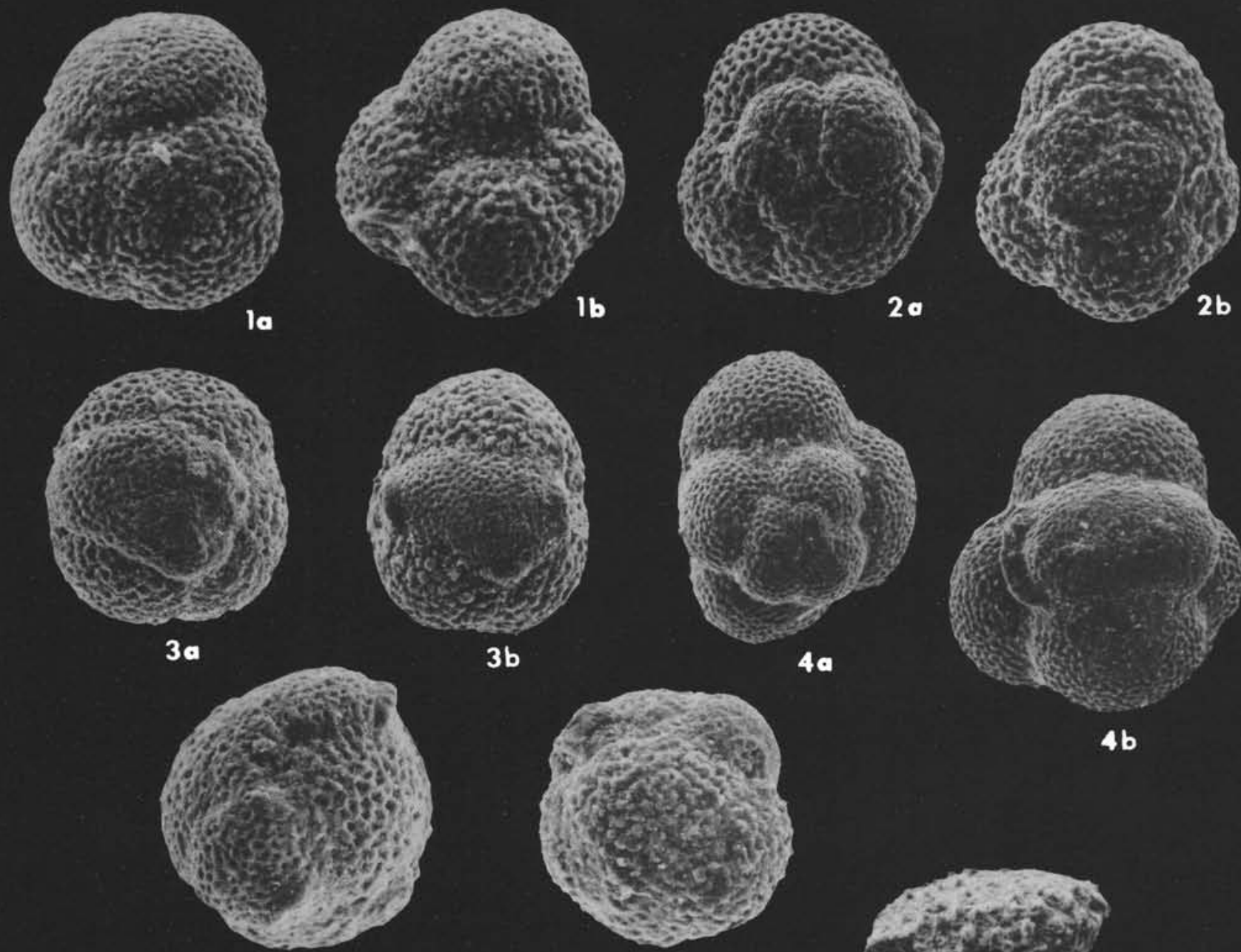

3b
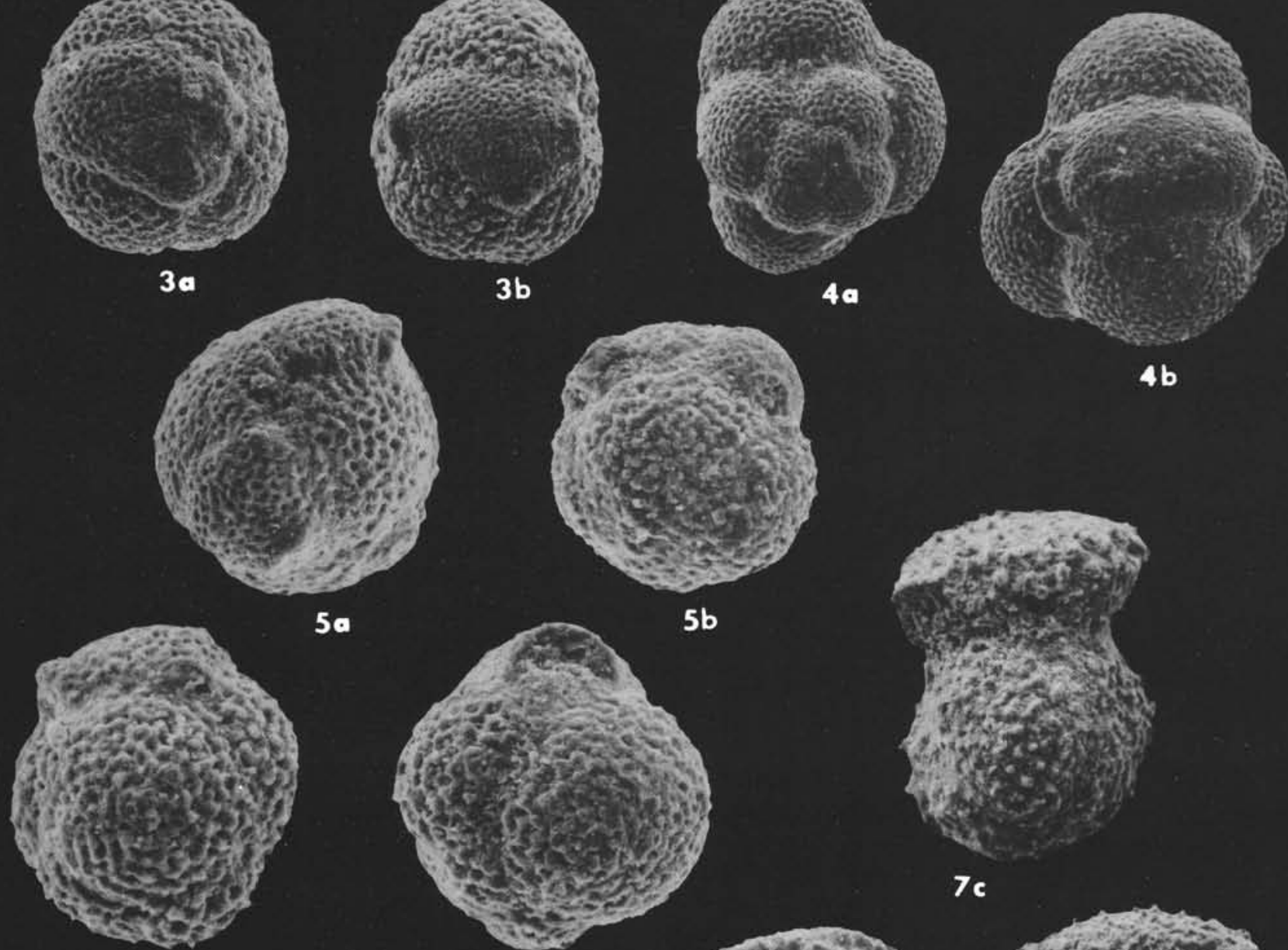

$5 a$

$5 b$

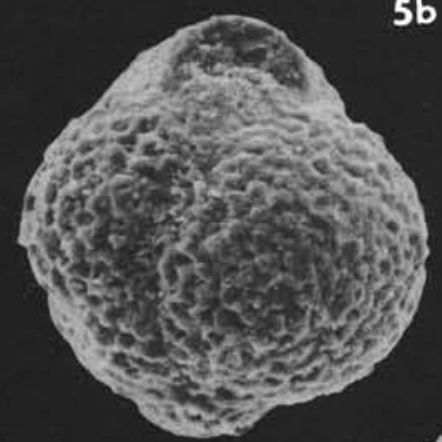

$6 a$

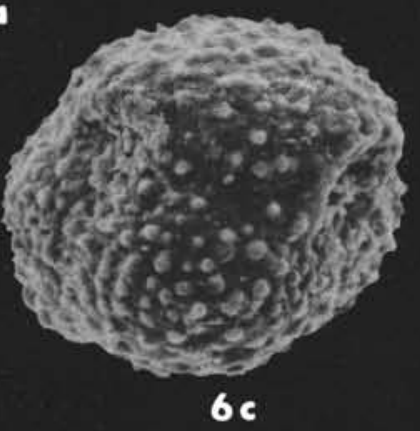

6b

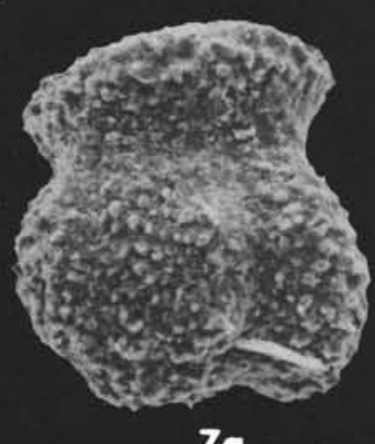

46

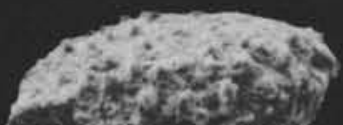

cos:
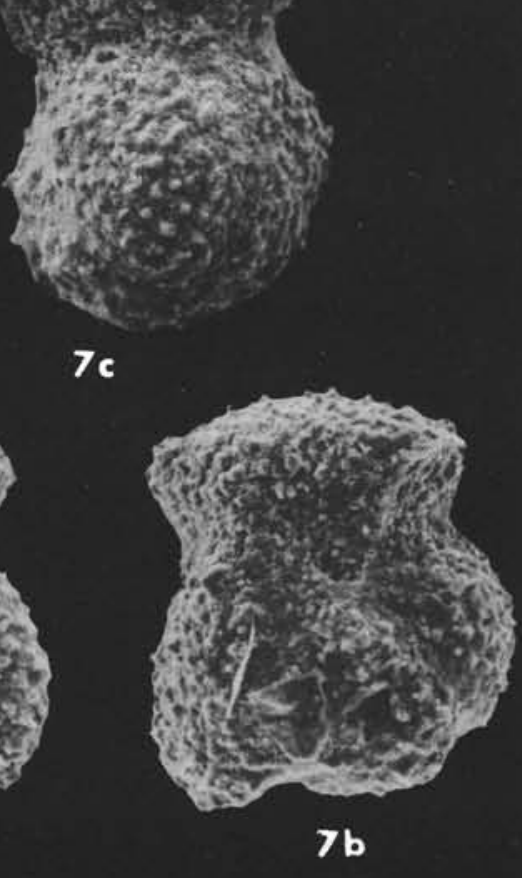
PLATE 11

Late Eocene, Oligocene

( $\mathrm{a}=$ spiral view, $\mathrm{b}=$ umibilical view, $\mathrm{c}=$ edge view for Figures 6 and 8 . Stereoscan illustrations, Laboratoire de Géologie, Muséum National d'Histoire Naturelle, Paris)

Figure 1 Globorotalia (Turborotalia) cerroazulensis var. cerroazulensis (Cole, 1928). Edge view, X185. Sample 242-19-3, $100 \mathrm{~cm}$; early late Eocene.

Figure 2 Globigerina gortanii Borsetti, 1959. Edge view, X45. Sample 242-15, CC; latest Eocene.

Figure 3 Globorotalia (Turborotalia) cerroazulensis var. cunialensis Toumarkine and Bolli, 1970. Edge view, X80. Sample 242-15, CC; latest Eocene.

Figure 4 Hantkenina primitiva Cushman and Jarvis, 1929. Lateral view, X85. Sample 242-19-3, $100 \mathrm{~cm}$; early late Eocene.

Figure $5 \quad$ Globigerina ampliapertura Bolli, 1957. (a) $\times 115$, (b) $\times 140$, and (c) $\times 155$. Sample 242-15-3, $50 \mathrm{~cm}$; latest Eocene; same exemplar for (a) and (c).

Figure 6 Globoquadrina tapuriensis Blow and Banner, 1962. (a), (b) and (c) $\times 85$. Sample 242-15-1, $30 \mathrm{~cm}$; earliest Oligocene.

Figure 7 Hantkenina alabamensis Cushman, 1924. (a) Lateral view, X85, and (b) Edge view, X85. Sample 242-15-3, $100 \mathrm{~cm}$; latest Eocene.

Figure $8 \quad$ Globigerina (?Globigerina) prasaepis Blow, 1969. (a), (b) and (c) $\times 80$. Sample 242-15-1, $100 \mathrm{~cm}$; latest Eocene. 
PLATE 11
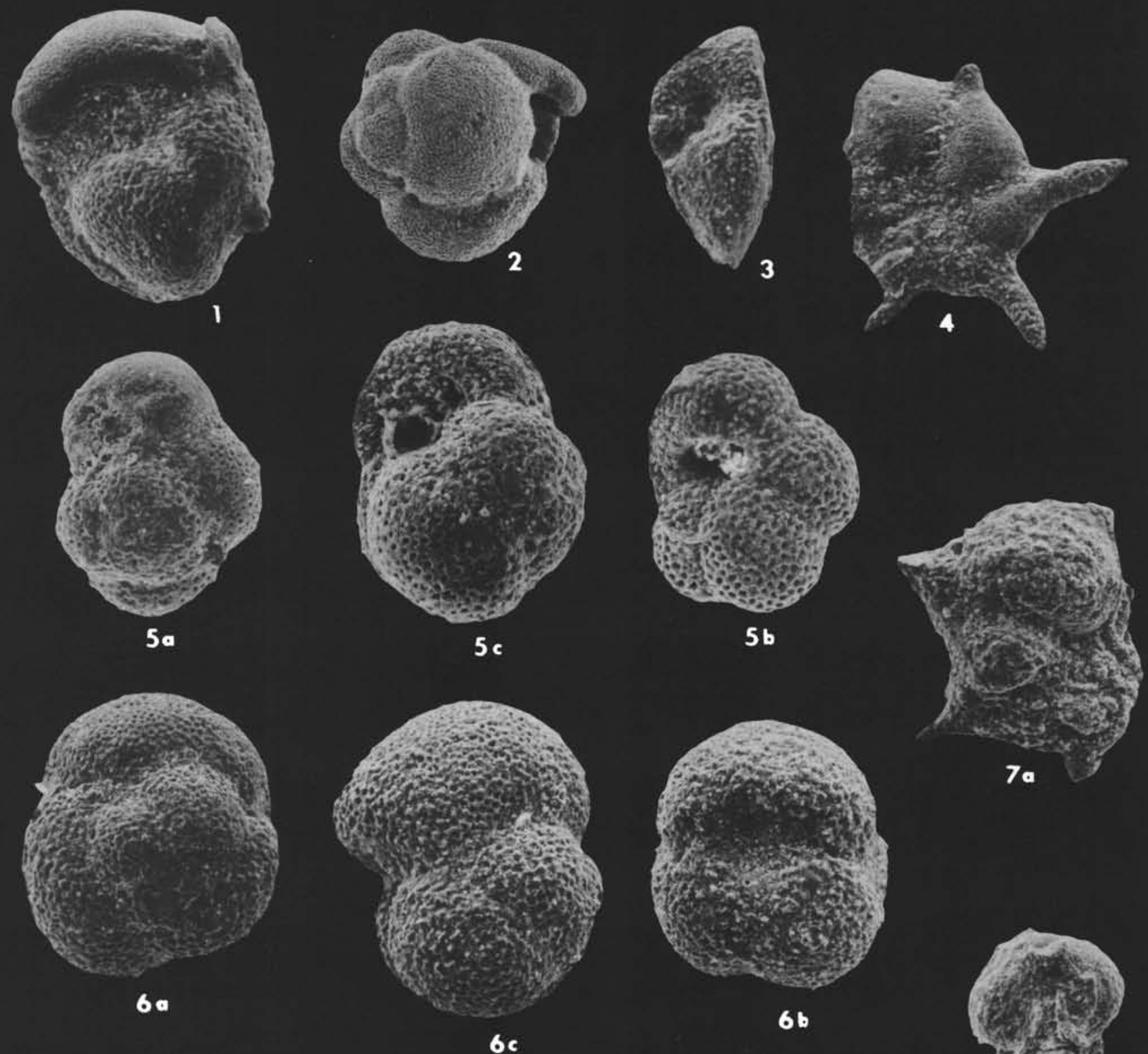

6c

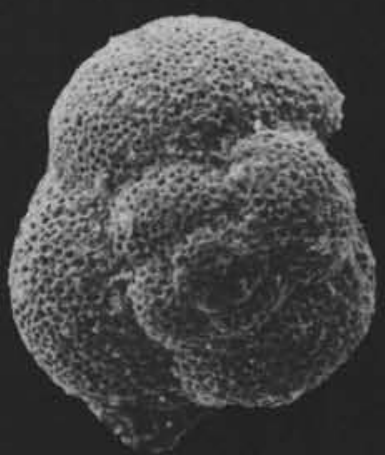

8a

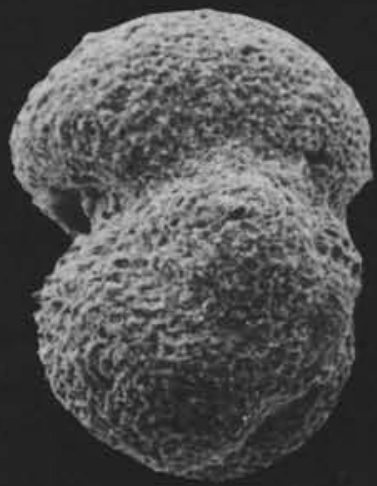

$8 c$
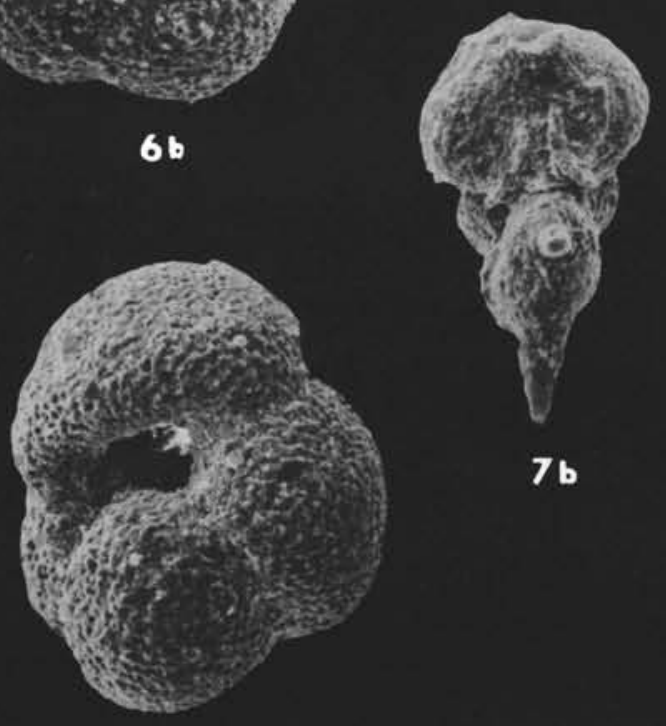

$7 b$

$8 b$ 